\title{
Towards Circular Economy-A Comparative Analysis of the Countries of the European Union
}

\author{
Ewa Mazur-Wierzbicka (iD
}

check for updates

Citation: Mazur-Wierzbicka, E.

Towards Circular Economy-A

Comparative Analysis of the

Countries of the European Union.

Resources 2021, 10, 49. https://

doi.org/10.3390/resources10050049

Academic Editors: Sebastian Kot and Robert Stefko

Received: 20 January 2021

Accepted: 6 May 2021

Published: 13 May 2021

Publisher's Note: MDPI stays neutral with regard to jurisdictional claims in published maps and institutional affiliations.
Institute of Management, University of Szczecin, 70-453 Szczecin, Poland; ewa.mazur-wierzbicka@usz.edu.pl

\begin{abstract}
There are many studies which implement and assess existing measurement manners and document the progress of entities towards the circular economy (CE) at various levels, or present or propose new possibilities of measurement. The majority of them refer to the micro level. The aim of this paper is to conduct a multidimensional comparative analysis of the implementation of circular economy by EU countries. After an in-depth critical analysis of the literature, CE indicators which were proposed by the European Commission were adopted as a basis. Owing to the research population-Member States of the European Union (EU-28), focusing on the said indicators was declared reasonable in all aspects. The classification of EU countries according to the level of their advancement in the concept of CE was adopted as a main research task. In order to do so, a relevant index of development of circular economy was created (IDCE). This will allow us, inter alia, to trace changes in the spatial differentiation of advancement of the EU countries in implementing CE over the years, to identify CE implementation leaders as well as countries particularly delayed in this regard. The comparative analysis was conducted by means of statistical methods. On the basis of the analyses, it was concluded that among all EU countries, those of the old EU are the most advanced in terms of CE. The analysis confirmed significant rising trends for IDCE only in the case of Belgium and The Netherlands.
\end{abstract}

Keywords: circular economy; EU countries; indicators

\section{Introduction}

Despite the growing degradation of the natural environment, most economies throughout the world are functioning on the basis of the traditional linear economy, in brief based on the "take-use-dispose" model [1,2]. This model wrongly assumes the infinity of natural resources and unlimited capacity of waste storage.

The linear model of business activity does not take into account environmental burdens generated in the production and consumption processes or the natural boundaries of economic growth resulting from the depletion of non-renewable resources (such as fossil fuels or minerals), and it results in insufficient use of resources and a constant demand for them [3-5]. The linear economy model has not proved effective-it turned out to be inefficient and short-lived [6,7].

The concept of circular economy (CE) that has its foundations as early as in the 1960s has been adopted by scholars and practitioners as an alternative to the model of linear economy [8]. At the moment, these foundations are based on a completely new paradigm (different to the mentioned linear business model) [9], according to which it is necessary to analyse the existing economic systems in detail and to reorganise them in order to increase the efficiency of use of natural resources, to transform waste into resources and to implement a new approach to production and consumption (the collaborative or sharing economy becomes significant for consumption [10-12] in order to minimise the production of waste and pollution). The CE concept is based on the "take-use-reuse" approach that involves closing the circuit of cycles of extended product life and treating waste as precious recyclable materials. It assumes minimising the negative impact of the production cycle of 
the natural environment. It is closely associated with the "from cradle to cradle" production method first defined by Stahel [13-16].

In the context of the development of the circular economy and the process of the transition of economies in this direction, relevant monitoring of the implementation of its goals and progress that individuals make in the micro, meso and macro scale is essential $[17,18]$. The condition for appropriately conducted monitoring involves having harmonised, measurable, and relevant diagnostic indicators [19].

The subject matter of CE implementation and its indicators are also addressed in studies drawn up by international organisations, e.g., the EU [20], the OECD [21], the World Bank [22], the WBCSD [23], the EEA [10], the Ellen MacArthur Foundation [24-27] and the EASAC [17].

Some countries, e.g., China [18,28-30] and EU Member States alike also develop national indicators of circular economy, thus supplementing the review included in the Union's regulations (the Netherlands [31-33], France [34,35], Italy [36,37], and Portugal [38]).

National indicators of CE monitoring are adjusted to the adopted strategies, policies and actions that are specific to a given country. This is an obstacle to making comparisons between countries. There is no single reference point for individual countries or groups of countries. We can also make such comparisons on the basis of indicators that have been identified and standardised for all countries, which guarantee reliable-Such were included, inter alia, in the European Commission's monitoring framework (works are underway to supplement them with those that monitor important $C E$ areas that are not yet being measured) [20]. The proposed monitoring framework is not, however, sufficiently detailed so as to measure aspects that are important at the regional and local level $[39,40]$.

Given the development of the CE concept at the micro, meso and macro level, the indicators intended to monitor its implementation require constant improvement and adjustment to priority goals.

Monitoring CE has been made very difficult due to the lack of a specific, universally acknowledged set of indicators or an indicator that would measure progress in implementing circular economy both at the level of enterprises, sectors, cities, regions or states [10,41-43] and due to continuous development of tools to measure CE.

The literature points to a still insufficient number of studies on CE assessment and CE indicators [41], at the same time demonstrating the rank and significance of well-developed indicators $[18,44,45]$.

When one enters the phrase "circular economy of the European Union countries and measurement" in the Scopus database, only two positions appear, one concerning the sustainability of Novel Foods in the phase of transitioning to circular economy [46], while the second is devoted to qualitative assessment of a coordinated set of dematerialisation policies, which aim at fostering the socially efficient use (and re-use) of virgin materials at firm level [47]. A search for "circular economy of the European Union countries and indicators" provides 26 results, where 18 are classified under Environmental Science, 13 fall under the Energy dimension, 9 are assigned to the Social Sciences field, 7 to the Engineering area and 5 to Business Management and Accounting. They concern inter alia the issue of measuring CE and its basic elements in the EU countries [48-52], but also the issues of, i.e., the significance of tertiary education in the EU countries for implementing the goals of circular economy in the energy sector [53], relations between selected indicators of a circular economy, including essential components of environmental and economic growth [54], determinants of circular economy in Europe [55], CE's challenges and capabilities [56], relations between circular economy and sustainable development goals $[57,58]$, the issues of $\mathrm{CE}$ in reference to smart cities [58], a model approach to $\mathrm{CE}$ [59] or CE literature review [60].

The created synthetic indicator is intended to be an additional, supplementary tool to allow the monitoring of progress in EU countries' transition to CE over the years. It is universal for all countries and it takes into account the same elements considered significant for the European Commission's monitoring of CE. Relevant international literature has 
produced many attempts to introduce synthetic indicators. They have been used for years to monitor various economic, social or environmental aspects, for example: the Commitment to Development Index (CDI), the Sustainable Society Index (SSI), the Happy Planet Index (HPI), the Index of Sustainable Economic Welfare (ISEW), the Index of Economic Well-Being (IEWS), the Environmental Sustainability Index (ESI), or the Environmental Performance Index (EPI).

The structure of a synthetic indicator allows the measurement of a multidimensional phenomenon and linear ordering of the investigated units. It allows researchers to take into consideration many aspects of the phenomenon investigated at the same time and facilitates inference at a higher level of a general outlook. Benefits in this regard include the quantification of a complex occurrence by means of one numeric value which facilitates all comparisons and synthesises partial images that concern the investigated elements. Results of ordering and classification in subsequent years of the examined period make it possible to specify the changes in the location of a unit with regard to others.

This is the reason for the attempt to build a synthetic CE indicator to measure circular economy at the macro level (here: suitable for EU countries) and to classify and group EU countries in terms of their advancement in CE implementation.

Thanks to the use of the proposed indicator, it will be possible to trace the changes in the spatial differentiation of the advancement of EU countries in implementing CE. This will be reflected in the individual countries changing places in the devised rankings of $\mathrm{CE}$ implementation progress for the years investigated.

Given the above, the paper's aim is to conduct a multidimensional comparative analysis of the implementation of circular economy by EU countries.

In order to do so, a suitable index of development of circular economy (IDCE) has been drafted.

The classification of EU countries according to their level of advancement in the concept of circular economy was adopted as the main research task.

$\mathrm{CE}$ indicators proposed by the European Commission formed the basis for the analysis. Due to the research subject, the EU-28, as well as after an in-depth critical analysis of the literature, the choice of indicators was believed justified in all respects. The Hellwig method, Euclidean distance algorithm, cluster analysis and regression analysis were used in the analysis.

The article is structured as follows: The introduction is followed by a theoretical section that sheds light on the essence of $\mathrm{CE}$ and the possibilities of monitoring it, which are essential from the point of view of the study, focusing on measuring circular economy in the European Union. Section 3 describes the research methodology. Section 4 includes the research results and a discussion. The final section is a summary of the article. This section also presents limitations of the research presented in the article, and directions of future research are indicated.

\section{Literature Review: Circular Economy-Essence of the Concept and Measuring}

As a result of the development of the CE concept in various fields (e.g., science, business, politics; micro, meso, macro), we currently have no clarity and thus a great diversity of understanding of circular economy. The concept of CE has been defined by researchers and institutions or organizations alike. The compilation of examples and various approaches to $C E$ is presented in Table 1.

The paper assumes CE to be an economy, where the value of products, materials and resources is maintained "(...) for as long as possible, and the generation of waste minimized" [14]. 
Table 1. Selected definitions of CE—approach to CE from the level of science, business and decision-makers.

\begin{tabular}{cc}
\hline Author & Explicit Definition of Circular Economy \\
\hline "A circular economy (CE) can be defined as an economic model aimed at the efficient \\
use of resources through waste minimisation, long-term value retention, reduction of \\
primary resources, and closed loops of products, product parts, and materials within the \\
boundaries of environmental protection and socioeconomic benefits. A CE has the \\
potential to lead to sustainable development, while decoupling economic growth from \\
the negative consequences of resource depletion and environmental degradation". \\
"CE is a sustainable development initiative with the objective of reducing the societal \\
production-consumption systems' linear material and energy throughput flows by \\
applying materials cycles, renewable and cascade-type energy flows to the linear system. \\
CE promotes high value material cycles alongside more traditional recycling and \\
develops systems approaches to the cooperation of producers, consumers and other \\
societal actors in sustainable development work."
\end{tabular}

"The circular economy is an economic system that represents a change of paradigm in the way that human society is interrelated with nature and aims to prevent the depletion of resources, close energy and materials loops, and facilitate sustainable development

Prieto-Sandoval et al., 2018 [40] through its implementation at the micro (enterprises and consumers), meso (economic agents integrated in symbiosis) and macro (city, regions and governments) levels.

Attaining this circular model requires cyclical and regenerative environmental innovations in the way society legislates, produces and consumes."

Geissdoerfer et al., 2017 [9]

Murray et al., 2017 [62]

Kirchherr et al., 2017 [63]

“CE as a regenerative system in which resource input and waste, emission, and energy leakage are minimised by slowing, closing, and narrowing material and energy loops.

This can be achieved through long-lasting design, maintenance, repair, reuse, remanufacturing, refurbishing, and recycling."

$\mathrm{CE}$ "is an economic model wherein planning, resourcing, procurement, production and reprocessing are designed and managed, as both process and output, to maximise ecosystem functioning and human well-being."

\footnotetext{
"A circular economy describes an economic system that is based on business models which replace the 'end-of-life' concept with reducing, alternatively reusing, recycling and recovering materials in production/distribution and consumption processes, thus operating at the micro level (products, companies, consumers), meso level (eco-industrial parks) and macro level (city, region, nation and beyond), with the aim to accomplish sustainable development, which implies creating environmental quality, economic prosperity and social equity, to the benefit of current and future generations." They defined CE as "an economic system that replaces the "end-of-life" concept with reducing, alternatively reusing, recycling and recovering materials in production/distribution and consumption processes, (...), with the aim to accomplish sustainable development, thus simultaneously creating environmental quality, economic prosperity and social equity, to the benefit of current and future generations".

The circular economy, defined as a "restorative or regenerative industrial system by intention and design".

A Circular Economy "design and business model strategies (that are) slowing, closing, and narrowing resource loops".

"The centre of a circular economy is the circular (closed) flow of raw materials and energy consumption in multiple phases".
}

Niero et al., 2017 [64]

Bocken et al., 2016 [65]

Franklin-Johnson et al., 2016 [66]

"The CE has been defined as an industrial system that is restorative or regenerative by intention and design. It replaces the end-of-life concept with restoration, shifts towards Hobson 2016 [67] the use of renewable energy, eliminates the use of toxic chemicals, which impair reuse and return to the biosphere, and aims for the elimination of waste through the superior design of materials, products, systems and business models".

Singh and Ordonez 2016 [68]

"CE is an economic strategy that suggests innovative ways to transform the current linear system of consumption into a circular one, while achieving economic sustainability with much needed material savings." 
Table 1. Cont.

Author

Gregson et al., 2015 [69]

Haas et al., 2015 [70]

Ma et al., 2014 [71]

Liu 2012 [72]

Geng et al., 2009 [73]

Yuan et al., 2008 [74]

Deloitte 2016 [75]

EMF 2013 [25]

WBCSD 2017 [23]

\section{Explicit Definition of Circular Economy}

“The circular economy seeks to stretch the economic life of goods and materials by retrieving them from post-production consumer phases. This approach too valorizes closing loops, but does so by imagining object ends in their design and by seeing ends as beginnings for new objects."

"The circular economy is a simple, but convincing, strategy, which aims at reducing both input of virgin materials and output of wastes by closing economic and ecological loops of resource flows."

"A circular economy is a mode of economic development that aims to protect the environment and prevent pollution, thereby facilitating sustainable economic development."

Circular economy is defined as "An economy system which is characterized by principle of sustainable growth and depends less on depletion of natural resources than traditional economies through the mechanism of recycling the waste output of its system."

"an economy based on a spiral loop, i.e., a system that minimizes matter, energy flow and environmental deterioration without limiting economic growth or social and technical advancement".

"the core of (the Circular Economy) is the circular (closed) flow of materials and the use of raw materials and energy through multiple phases".

$\mathrm{CE}$ "represents a development strategy that enables economic growth while optimising the consumption of natural resources through a profound transformation of production chains and consumption patterns, and the re-designing of industrial systems".

"A circular economy is an industrial system that is restorative or regenerative by intention and design. It replaces the 'end-of-life' concept with restoration, shifts towards the use of renewable energy, eliminates the use of toxic chemicals, which impair reuse, and aims for the elimination of waste through the superior design of materials, products, systems, and, within this, business models".

"The circular economy is a new way of looking at the relationships between markets, customers and natural resources. (...) The goal of CE is to retain as much value as possible from resources, products, parts and materials to create a system that allows for long life, optimal reuse, refurbishment, remanufacturing and recycling". for as long as possible, and the generation of waste minimised".

Source: author's compilation $[3,9,14,23,25,40,61-74,76]$.

The action taken as part of CE is supposed to result in the more sustainable and competitive functioning of economic systems at the micro level (which may be reflected, i.e., in business models [77,78], as is seen in CE measurement at this level [41,79]). It is also noticeable at the meso level [80], i.e., in the context of individual industries, taking into account, e.g., the driving factors, sustainable productivity practices and indicators [81], trends [82] and costs and benefits [83,84], or in the context of eco-industrial parks in countries such as the Netherlands [85], Brazil [86] or China [80,87]. When it comes to the macro level, it is reflected, i.e., on the level of individual countries, for example, Romania [4], Sweden [88], China [29,30], or communities of countries, e.g., the EU [48,75,89].

In principle, the introduction of circular economy is intended to bring economic, social [90-92] and environmental [93] benefits [80,93,94], and eventually to build a system in which economy, society and natural environment are coordinated in terms of sustainable development goals [95]. It is evident that the CE vision is treated by many researchers and practitioners as support in the implementation of sustainable development goals [54,96-98], also in individual industries [99].

$\mathrm{CE}$ is the current priority of the economic policy of the European Union, which is why the EU puts a lot of effort into transforming its economy into a circular economy. In order 
to do so, the European Commission (EC) has taken a number of measures and adopted a few significant documents and regulations, thanks to which the EU has implemented a new legal framework that allows the transition of the economy into a circular economy in order to strengthen the economy, increase competitiveness and ensure future economic growth. The document, entitled Circular Economy Action Plan [14], is of fundamental importance as it includes a set of proposals for action in the coming years to be implemented by the $\mathrm{EU}$ and which are to contribute to a change in the model of economic development. These actions focus on a few priority areas, such as plastic, food waste, critical raw materials, construction and demolition waste and also biomass and bioproducts. The document also emphasises the role of innovation in transitioning towards the CE. By means of this document, it was suggested that all EU Member States transition from the model of linear economy to circular economy. However, it needs to be emphasised that $\mathrm{CE}$ aspects first appeared in EU policies and regulations as early as the 1970s. The following may be cited as examples: regulations concerning waste [100-103], the assessment of the impact of some public and private undertakings on the environment [104], recycling of end-of-life vehicles [105], used electrical and electronic equipment [106], the thematic strategy on the sustainable use of natural resources [107], and regulating the issues related to effective resource management [108]. In the last two years, the European Commission has proposed a framework for monitoring the CE [20] and has adopted a document entitled "A new Circular Economy Action Plan. For a cleaner and more competitive Europe" [109]. Both the documents adopted by the EU and the planned financial resources allocated to the implementation of the resulting tasks demonstrate that the EU perceives $\mathrm{CE}$ as the main point of its future economic and environmental policy. If CE were truly implemented, it may have a transformational impact on the economies of EU Member States. However, one needs to bear in mind the barriers associated with full CE implementation as envisaged by the EU [110-112].

In the case of the EU, almost every project at the European level is given "its own set of indicators". This leads to difficulties in comparing the effects of CE activities or the implementation of circular economy strategies between entities.

It is indisputable that in order to disseminate and implement and also effectively carry out the $\mathrm{CE}$ concept, it is necessary to construct the relevant tools to monitor and assess it, i.e., indicators to measure the progress in implementing circular economy $[113,114]$. It is also important to adopt such a system of indicators that will be universally applied and which will enable comparisons between the outcomes of CE functioning or the outcomes of progress in implementing it. It was also noticed by the European Commission, which concluded in the document "Closing the loop-An EU action plan for the Circular Economy" that "In order to assess progress towards a more circular economy and the effectiveness of action at EU and national level, it is important to have a set of reliable indicators" [14].

Its effect included works undertaken by the European Commission on the creation of a CE monitoring framework. The European Commission drew on European Environment Agency (EEA) experience and studies, with which it collaborated closely (the European Environment Agency published a report that listed indicators already available and those which required development and those which could be used to monitor progress towards circular economy), and used the studies compiled by Eurostat, the Resource Efficiency Scoreboard, and the Raw Materials Scoreboard [115]. It also held consultations with Member States in terms of monitoring CE. The monitoring framework created by the European Commission refers to the presented concept of CE first published in a 2015 European Commission document.

The CE monitoring framework $[20,116]$ is based on a set of ten indicators (part of which is divided into sub-indicators) that include each stage of the product lifecycle and innovation and competitiveness aspects. The indicators are grouped into four areas of CE policy strictly connected with priority areas included in the EU action plan for the circular economy [14]. The great majority of indicators taken into account in the monitoring 
framework do not have suitable targets or are followed by political activity, which limits them to a purely informative role.

Among the identified CE indicators included in the EU monitoring framework, all except two that are under development are included in other European frameworks (the Resource Efficiency Scoreboard, the Raw Materials Scoreboard, the Waste Framework Directive) [51]. Data for green public procurement indicators are still not available. Data measurement for the "food waste" indicator was stipulated in the amendment to the EU directive on waste [14]. Two indicators under development are associated with sustainable development goals of sustainable consumption and production [20]. Most of the indicators included in the EU monitoring framework focus on waste, which, according to the European Economic and Social Committee, results to a great degree from the fact that "data on waste is strong, consistent and comparable. However, any future monitoring needs to move beyond waste and recycling (...)" [117].

Pursuant to the EU's action plan for sustainable economy (Circular Economy Action Plan), the so-called European Green Deal, and the Annual Sustainable Growth Strategy 2020 [118], the Commission will update the framework of monitoring circular economy and will also reinforce the monitoring of national plans and measures that aim to accelerate their transition to circular economy.

\section{Methods}

Drawing conclusions regarding the research subject, the implementation of the adopted goal and research task required in-depth literature studies, mainly as regards monitoring $\mathrm{CE}$ on a macro scale, and a comparative analysis.

The author has carried out a thorough analysis of available CE indicators used in the EU Member States. An attempt was made to compare them and to verify the completeness of data. The collected material did not provide a basis to select indicators that would meet the required criteria for reliable research and for pursuing the goal set in the paper.

In the end, indicators employed in the EC's CE monitoring framework were used to carry out the analysis. Those indicators were assessed by the EU in terms of their usefulness, reliability, acceptability and soundness $[20,116]$. To date, they are the only framework for monitoring $\mathrm{CE}$ throughout the world developed at a pan-national level. They are consistent with the European Commission's goals included in fundamental EU documents. They focus on the macro level that is also the subject of this analysis.

Deduction and induction were used in the research process and a comparative analysis in time and space was performed. When selecting research methods, the author was mostly guided by the possibility of a broad look at the adopted research subject matter. Quantification of the examined phenomena was possible thanks to the use of an array of statistical methods. All analyses were performed in the Statistica v.13.1. package.

The research covers 28 EU Member States (EU-28), which is the territorial scope of the research. The adopted research period is 2010-2018. The year 2010 was adopted as the beginning of the analysis due to the availability of statistical data selected for the research and entry into force of the Europe 2020 strategy in which CE-related aspects were included.

The adopted research subject that addresses the level of advancement of the countries of the European Union towards circular economy is a very complex issue. The classified objects (states) are described by means of a number of indicators. This leads to difficulties associated with the assessment of the similarity of objects and thus their classification. The degree of similarity of objects in terms of one feature may be different to the similarity of these objects in terms of another feature. Therefore, there is a need to classify objects by means of formal procedures that allow the performance of objective research in conditions characteristic to circular economy [119].

The selection of relevant diagnostic variables which would fully characterise the discussed issue carries great importance in the research. The most important criterion for the selection of variables applied in the analysis was the substantive criterion. The assessment of diagnostic variables in these terms was conducted taking into account the 
following principles: universality, measurability, availability of quantitative data, data quality and interpretability [119].

When performing the analysis, firstly, all indicators included in the monitoring framework were identified. Then, attributes with the least diagnostic value were eliminated from the original set. A set of data selected in this way guaranteed considerable capacity for diagnostics, i.e., it was not too abundant and at the same time ensured a relatively universal description of the object investigated.

The research takes into account partial indicators which include information for all EU Member States. Indicators for which the data was aggregated (self-sufficient for raw material and contribution of recycled material to raw materials demand) and those not entirely developed or included in statistics (Green Public Procurement, Food waste) were eliminated.

Eventually, 13 circular economy indicators were qualified to the research [20]. They included:

- Generation of municipal waste per capita;

- Generation of waste excluding major mineral waste per GDP unit;

- Generation of waste excluding major mineral waste per domestic material consumption;

- Recycling rate of municipal waste;

- Recycling rate of all waste excluding major mineral waste;

- Recycling rate of packaging waste by type of packaging;

- Recycling rate of e-waste;

- Recycling of biowaste;

- Recovery rate of construction and demolition waste;

- Circular material use rate;

- Trade in recyclable raw materials;

- Private investments, jobs and gross value added related to circular economy sectors;

- Patents related to recycling and secondary raw materials.

In order to carry our linear ordering so as to create the synthetic dependent variable $\mathrm{Y}_{\text {IDCE }}$-IDCE (index of development of circular economy) according to the Hellwig concept (1968) [120] or on the basis of the pattern method, first the vector of analysed variables was standardised. A literature query demonstrates that the following have the best formal properties: the classical standardisation method and the unitarisation method. The second method also meets the condition of negativity postulated by some authors and is the method that was applied when constructing IDCE $\mathrm{Y}_{\text {IDCE }}$ indicators. Normalisation runs according to the following formulas:

$$
\rightarrow \quad x_{i j}=\frac{x_{i j}-\min _{i}\left\{x_{i j}\right\}}{\max _{i}\left\{x_{i j}\right\}-\min _{i}\left\{x_{i j}\right\}}
$$

for stimulants

$$
\rightarrow x_{i j}=\frac{\max _{i}\left\{x_{i j}\right\}-x_{i j}}{\max _{i}\left\{x_{i j}\right\}-\min _{i}\left\{x_{i j}\right\}}
$$

for distimulants

where subscript $i$ denotes the object number and subscript $j$ is the attribute number.

The relevant extreme values should be sought in the objects set for a given attribute [121].

On the basis of the matrix of standardised input data, a pattern object with the following coordinates (standardised variable values) was established:

$$
\mathbf{O}_{0}=\left[z_{o j}\right], j=1,2, \ldots, m .
$$


Coordinates of a pattern object were established on the basis of the following formula:

$$
z_{o j}=\left\{\begin{array}{l}
\max _{i}\left\{z_{i j}\right\} \text { for } z_{j}^{S} \\
\min _{i}\left\{z_{i j}\right\} \text { for } z_{j}^{D}
\end{array}, j=1,2, \ldots, m .\right.
$$

Then, the distance of each object from the pattern object was measured by means of a Euclidean matrix in the form presented below. At this point, multidimensional space was reduced to one dimension presented by the newly created variable $d_{i 0}$ :

$$
d_{i 0}=\left[\sum_{j=1}^{m}\left(z_{i j}-z_{0 j}\right)^{2}\right]^{\frac{1}{2}}, i=1,2, \ldots, \mathrm{m}
$$

The synthetic measure was eventually defined as:

$$
\mathrm{Y}_{\text {IDCEHellwig'smethod }}=1-\frac{d_{i 0}}{d_{0}}, i=1,2, \ldots, m,
$$

where:

$$
d_{0}=\bar{d}_{0}+2 S\left(d_{0}\right)
$$

where:

$$
\bar{d}_{0}=\frac{1}{n} \sum_{i=1}^{n} d_{i 0} ; S\left(d_{0}\right)=\left[\frac{1}{n} \sum_{i=1}^{n}\left(d_{i 0}-\bar{d}_{0}\right)^{2}\right]^{\frac{1}{2}} .
$$

Measure $d_{i}$ usually take values from the range $[0 ; 1]$. The closer a given object is from the pattern, the higher these values are.

In the case of the pattern method, variables must have the nature of stimulants or distimulants. They must be standardised.

Therefore, the first pattern:

$$
z_{0}=\left[\begin{array}{llll}
z_{01} & z_{02} & \ldots & z_{0 m}
\end{array}\right], \text { where } z_{0 j}=\left\{\begin{array}{l}
\max _{i} z_{i j} \text { for a stimulant } \\
\max _{i} \operatorname{ax} z_{i j} \text { for a distimulant }
\end{array}\right.
$$

and the anti-pattern:

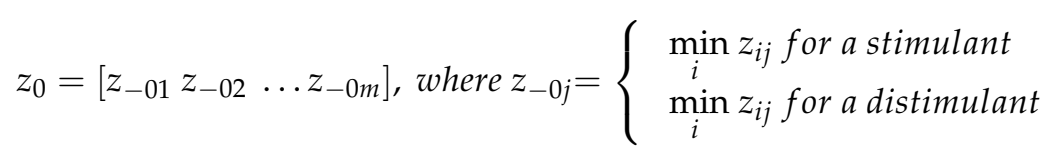

were set.

They are abstract objects with best and worst values.

Then, the distance of each object from the pattern was calculated by means of the Euclidean matrix.

$$
d_{i 0}=\left[\sum_{j=1}^{m}\left(z_{i j}-z_{0 j}\right)^{2}\right]^{\frac{1}{2}}, i=1,2, \ldots, m
$$

In the next stage, the development measure, i.e., IDCE, was established:

$$
Y_{\text {IDCEpattenmethod }}=1-\frac{d_{i 0}}{d_{0}}
$$

where $d_{0}$ means the difference between the pattern and the anti-pattern. The higher the IDCE- $Y_{\text {IDCE }}$, the higher the level of the complex phenomenon, $Y_{\text {IDCE }} \in[0,1]$. 
In a further analysis, taxonomic methods were used in the form of a cluster analysis, where tree diagrams were obtained on the basis of the agglomerative approach (Ward's method) with the distance measure in the form of the Euclidean distance. Diagrams were created for standardised values on the basis of the above-mentioned method for stimulants and distimulants. Thanks to the application of a cluster analysis, object grouping was performed.

In the last stage of the analyses, the significance of trends for the IDCE synthetic variables of the analysed countries in the adopted research period was verified.

\section{Research Results and Discussion}

The analysis performed by the author focused on the assessment of the level of progress of European Union countries towards circular economy.

The research analysis began with selecting diagnostic variables. Then, raw variables were transformed into standardised variables. In the next stage of analyses, dimensions were reduced and the IDCE synthetic variable was constructed. The closer IDCE is to 1, the closer to a pattern a given country is.

Data included in Table 2 show that apart from 2010, in all other cases the best results closest to the pattern of the IDCE synthetic variable were achieved for Germany, France and the Netherlands. The worst results were obtained by Malta, Greece, Cyprus and Croatia. This section may be divided by subheadings. It should provide a concise and precise description of the experimental results, their interpretation as well as the experimental conclusions that can be drawn.

Table 2. A summary of values of the IDCE synthetic variable for the EU-28 countries for 2010-2018.

\begin{tabular}{|c|c|c|c|c|c|c|c|c|c|}
\hline \multirow{2}{*}{ Country } & \multicolumn{9}{|c|}{$Y_{\text {IDCE }}$} \\
\hline & 2010 & 2011 & 2012 & 2013 & 2014 & 2015 & 2016 & 2017 & 2018 \\
\hline Belgium & 0.521 & 0.482 & 0.530 & 0.510 & 0.536 & 0.469 & 0.618 & 0.548 & 0.591 \\
\hline Bulgaria & 0.348 & 0.295 & 0.305 & 0.330 & 0.379 & 0.345 & 0.454 & 0.379 & 0.329 \\
\hline Czechia & 0.477 & 0.298 & 0.486 & 0.326 & 0.483 & 0.318 & 0.537 & 0.381 & 0.377 \\
\hline Denmark & 0.356 & 0.342 & 0.490 & 0.371 & 0.522 & 0.357 & 0.567 & 0.380 & 0.403 \\
\hline Germany & 0.682 & 0.746 & 0.763 & 0.725 & 0.668 & 0.665 & 0.598 & 0.690 & 0.739 \\
\hline Estonia & 0.321 & 0.361 & 0.325 & 0.307 & 0.289 & 0.272 & 0.315 & 0.338 & 0.315 \\
\hline Ireland & 0.413 & 0.282 & 0.442 & 0.159 & 0.457 & 0.125 & 0.476 & 0.314 & 0.004 \\
\hline Greece & 0.290 & 0.245 & 0.238 & 0.200 & 0.236 & 0.198 & 0.393 & 0.289 & 0.089 \\
\hline Spain & 0.564 & 0.471 & 0.535 & 0.531 & 0.547 & 0.465 & 0.590 & 0.536 & 0.614 \\
\hline France & 0.620 & 0.544 & 0.598 & 0.545 & 0.626 & 0.513 & 0.609 & 0.553 & 0.497 \\
\hline Croatia & 0.243 & 0.102 & 0.329 & 0.190 & 0.383 & 0.252 & 0.467 & 0.325 & 0.297 \\
\hline Italy & 0.595 & 0.508 & 0.581 & 0.514 & 0.568 & 0.481 & 0.590 & 0.501 & 0.577 \\
\hline Cyprus & 0.274 & 0.139 & 0.305 & 0.157 & 0.303 & 0.165 & 0.349 & 0.151 & 0.000 \\
\hline Latvia & 0.301 & 0.216 & 0.281 & 0.258 & 0.363 & 0.222 & 0.404 & 0.297 & 0.320 \\
\hline Lithuania & 0.393 & 0.254 & 0.430 & 0.279 & 0.478 & 0.271 & 0.563 & 0.384 & 0.540 \\
\hline Luxembourg & 0.581 & 0.423 & 0.538 & 0.380 & 0.531 & 0.347 & 0.555 & 0.414 & 0.466 \\
\hline Hungary & 0.405 & 0.278 & 0.366 & 0.276 & 0.418 & 0.262 & 0.473 & 0.325 & 0.386 \\
\hline Malta & 0.251 & 0.145 & 0.305 & 0.126 & 0.304 & 0.079 & 0.337 & 0.098 & 0.105 \\
\hline Netherlands & 0.633 & 0.588 & 0.630 & 0.568 & 0.639 & 0.562 & 0.693 & 0.685 & 0.719 \\
\hline Austria & 0.594 & 0.483 & 0.584 & 0.479 & 0.585 & 0.444 & 0.621 & 0.519 & 0.605 \\
\hline Poland & 0.479 & 0.312 & 0.440 & 0.295 & 0.482 & 0.404 & 0.498 & 0.359 & 0.399 \\
\hline
\end{tabular}


Table 2. Cont.

\begin{tabular}{cccccccccc}
\hline \multirow{2}{*}{ Country } & \multicolumn{7}{c}{ Y $_{\text {IDCE }}$} \\
\cline { 2 - 9 } & $\mathbf{2 0 1 0}$ & $\mathbf{2 0 1 1}$ & $\mathbf{2 0 1 2}$ & $\mathbf{2 0 1 3}$ & $\mathbf{2 0 1 4}$ & $\mathbf{2 0 1 5}$ & $\mathbf{2 0 1 6}$ & $\mathbf{2 0 1 7}$ & $\mathbf{2 0 1 8}$ \\
\hline Portugal & 0.410 & 0.290 & 0.442 & 0.324 & 0.479 & 0.299 & 0.523 & 0.351 & 0.445 \\
\hline Romania & 0.362 & 0.232 & 0.363 & 0.239 & 0.358 & 0.215 & 0.420 & 0.224 & 0.307 \\
\hline Slovenia & 0.429 & 0.325 & 0.490 & 0.320 & 0.485 & 0.343 & 0.575 & 0.418 & 0.496 \\
\hline Slovakia & 0.364 & 0.287 & 0.363 & 0.297 & 0.399 & 0.265 & 0.437 & 0.339 & 0.373 \\
\hline Finland & 0.420 & 0.370 & 0.398 & 0.339 & 0.464 & 0.319 & 0.489 & 0.350 & 0.380 \\
\hline Sweden & 0.589 & 0.507 & 0.581 & 0.490 & 0.537 & 0.416 & 0.559 & 0.459 & 0.533 \\
\hline $\begin{array}{c}\text { United } \\
\text { Kingdom }\end{array}$ & 0.589 & 0.487 & 0.556 & 0.493 & 0.566 & 0.477 & 0.612 & 0.421 & 0.430
\end{tabular}

Source: author's compilation. Source: https://ec.europa.eu/eurostat/data/database; https://ec.europa.eu/eur ostat/cache/scoreboards/CE_DataBro/index.html (accessed on 10 September 2020).

The calculated values of the synthetic indicator allow the ordering of the set of countries in terms of the phenomenon investigated, thus outlining the rank of each country in relation to others. The greater the value of the indicator, the higher the country's position in the ranking. On the basis of IDCE, a ranking of $28 \mathrm{EU}$ countries was drafted in terms of their advancement towards circular economy in 2010-2018.

On the basis of the data included in Table 3, it may be concluded that the highest positions in the analysed years in the constructed ranking were obtained by Germany, the Netherlands and France, which means that these countries are most advanced in their pursuit towards circular economy among the states investigated. Malta, Greece and Cyprus took lower positions.

The results compiled in Table 2 confirmed the results presented in Table 3 and allowed a conclusion that the best results closest to the patterns were calculated for Germany, the Netherlands and France. The worst results were obtained by Malta, Greece, Cyprus and Croatia. Therefore, it can be concluded that the rankings of positions obtained on the basis of Hellwig's method and the pattern method based on the Euclidean distance are identical.

On the basis of the ranking (Table 3), one may point to an order in which the countries stand in terms of their advancement towards circular economy from the best to the worst in the subsequent analysed years.

Table 3. Ranking of the EU-28 countries according to the value of the IDCE synthetic variable for 2010-2018.

\begin{tabular}{cccccccccc}
\hline \multirow{2}{*}{ Country } & \multicolumn{1}{c}{ Ranking } \\
\cline { 2 - 11 } & $\mathbf{2 0 1 0}$ & $\mathbf{2 0 1 1}$ & $\mathbf{2 0 1 2}$ & $\mathbf{2 0 1 3}$ & $\mathbf{2 0 1 4}$ & $\mathbf{2 0 1 5}$ & $\mathbf{2 0 1 6}$ & $\mathbf{2 0 1 7}$ & $\mathbf{2 0 1 8}$ \\
\hline Belgium & 10 & 8 & 10 & 6 & 9 & 6 & 3 & 4 & 5 \\
\hline Bulgaria & 22 & 17 & 24 & 13 & 22 & 13 & 21 & 15 & 20 \\
\hline Czechia & 12 & 16 & 13 & 14 & 13 & 16 & 14 & 13 & 18 \\
\hline Denmark & 21 & 13 & 12 & 11 & 11 & 11 & 10 & 14 & 14 \\
\hline Germany & 1 & 1 & 1 & 1 & 1 & 1 & 6 & 1 & 1 \\
\hline Estonia & 23 & 12 & 23 & 17 & 27 & 18 & 28 & 20 & 22 \\
\hline Ireland & 15 & 20 & 14 & 26 & 18 & 27 & 18 & 23 & 27 \\
\hline Greece & 25 & 23 & 28 & 24 & 28 & 25 & 25 & 25 & 26 \\
\hline Spain & 9 & 9 & 9 & 4 & 7 & 7 & 8 & 5 & 3 \\
\hline France & 3 & 3 & 3 & 3 & 3 & 3 & 5 & 3 & 9 \\
\hline
\end{tabular}


Table 3. Cont.

\begin{tabular}{|c|c|c|c|c|c|c|c|c|c|}
\hline \multirow{2}{*}{ Country } & \multicolumn{9}{|c|}{ Ranking } \\
\hline & 2010 & 2011 & 2012 & 2013 & 2014 & 2015 & 2016 & 2017 & 2018 \\
\hline Croatia & 28 & 28 & 22 & 25 & 21 & 22 & 20 & 21 & 24 \\
\hline Italy & 4 & 4 & 5 & 5 & 5 & 4 & 7 & 7 & 6 \\
\hline Cyprus & 26 & 27 & 26 & 27 & 26 & 26 & 26 & 27 & 28 \\
\hline Latvia & 24 & 25 & 27 & 22 & 23 & 23 & 24 & 24 & 21 \\
\hline Lithuania & 18 & 22 & 17 & 20 & 16 & 19 & 11 & 12 & 7 \\
\hline Luxembourg & 8 & 10 & 8 & 10 & 10 & 12 & 13 & 11 & 11 \\
\hline Hungary & 17 & 21 & 19 & 21 & 19 & 21 & 19 & 22 & 16 \\
\hline Malta & 27 & 26 & 25 & 28 & 25 & 28 & 27 & 28 & 25 \\
\hline Netherlands & 2 & 2 & 2 & 2 & 2 & 2 & 1 & 2 & 2 \\
\hline Austria & 5 & 7 & 4 & 9 & 4 & 8 & 2 & 6 & 4 \\
\hline Poland & 11 & 15 & 16 & 19 & 14 & 10 & 16 & 16 & 15 \\
\hline Portugal & 16 & 18 & 15 & 15 & 15 & 17 & 15 & 17 & 12 \\
\hline Romania & 20 & 24 & 20 & 23 & 24 & 24 & 23 & 26 & 23 \\
\hline Slovenia & 13 & 14 & 11 & 16 & 12 & 14 & 9 & 10 & 10 \\
\hline Slovakia & 19 & 19 & 21 & 18 & 20 & 20 & 22 & 19 & 19 \\
\hline Finland & 14 & 11 & 18 & 12 & 17 & 15 & 17 & 18 & 17 \\
\hline Sweden & 6 & 5 & 6 & 8 & 8 & 9 & 12 & 8 & 8 \\
\hline United Kingdom & 7 & 6 & 7 & 7 & 6 & 5 & 4 & 9 & 13 \\
\hline
\end{tabular}

Source: author's compilation. Source: as in Table 2.

Subsequently, a cluster analysis was performed in the analysis of the results of variables of standardised stimulants and distimulants. Therefore, the next stage of research involved identifying groups of countries similar in terms of their level of advancement towards CE. Ward's method was applied for this purpose. Distance matrices between the analysed countries for 2010-2018 were used for the calculations. Using a distance matrix, the countries were classified into uniform, typological groups.

Table 4 includes a compilation of results of a cluster analysis (by means of Ward's method) according to a synthetic variable for the EU countries in the years 2010-2018. It includes the cut-off point, that is the minimum distance of the linkage, which is the basis for linking clusters, the number of clusters, as well as groups with the best and the worst results.

Table 4. Compilation of the results of a cluster analysis by means of Ward's method for the IDCE synthetic variable for the EU-28 countries in the years 2010-2018.

\begin{tabular}{|c|c|c|c|c|c|}
\hline Year & $\begin{array}{l}\text { Cut-Off } \\
\text { Point }\end{array}$ & $\begin{array}{l}\text { Number of } \\
\text { Clusters }\end{array}$ & $\begin{array}{l}\text { Group with the Best Results for } \\
\text { the Values of the IDCE } \\
\text { Synthetic Variable } \\
\text { (Number-Countries) }\end{array}$ & $\begin{array}{l}\text { Group with the Worst Results } \\
\text { for the Values of the IDCE } \\
\text { Synthetic Variable } \\
\text { (Number-Countries) }\end{array}$ & Other Groups \\
\hline 2010 & 2.5 & 3 & $\begin{array}{c}\text { I } \\
\text { (Belgium, Finland, Germany, } \\
\text { Austria, Sweden, Luxembourg, } \\
\text { Netherlands, Spain, France, Italy, } \\
\text { United Kingdom) }\end{array}$ & $\begin{array}{c}\text { III } \\
\text { (Greece, Cyprus, Malta, Croatia, } \\
\text { Latvia, Slovakia, Romania) }\end{array}$ & $\begin{array}{c}\text { III } \\
\text { (Denmark, Bulgaria, } \\
\text { Ireland, Czechia, Lithuania, } \\
\text { Hungary, Portugal, } \\
\text { Slovenia, Poland, Estonia) }\end{array}$ \\
\hline
\end{tabular}


Table 4. Cont.

\begin{tabular}{|c|c|c|c|c|c|}
\hline Year & $\begin{array}{l}\text { Cut-Off } \\
\text { Point }\end{array}$ & $\begin{array}{l}\text { Number of } \\
\text { Clusters }\end{array}$ & $\begin{array}{l}\text { Group with the Best Results for } \\
\text { the Values of the IDCE } \\
\text { Synthetic Variable } \\
\text { (Number-Countries) }\end{array}$ & $\begin{array}{c}\text { Group with the Worst Results } \\
\text { for the Values of the IDCE } \\
\text { Synthetic Variable } \\
\text { (Number-Countries) }\end{array}$ & Other Groups \\
\hline 2011 & 1.6 & 4 & $\begin{array}{c}\text { I } \\
\text { (Belgium, Luxembourg, } \\
\text { Netherlands, Denmark, } \\
\text { Austria, Sweden) } \\
\text { II } \\
\text { (Germany, Spain, France, Italy, } \\
\text { United Kingdom) }\end{array}$ & $\begin{array}{c}\text { IV } \\
\text { (Croatia, Cyprus, Malta) }\end{array}$ & $\begin{array}{c}\text { III } \\
\text { (Bulgaria, Ireland, Greece, } \\
\text { Portugal, Estonia, Slovenia, } \\
\text { Finland, Czechia, Lithuania, } \\
\text { Hungary, Slovakia, Latvia, } \\
\text { Romania, Poland) }\end{array}$ \\
\hline 2012 & 2.4 & 3 & $\begin{array}{c}\text { I } \\
\text { (Belgium, Netherlands, Spain, } \\
\text { Sweden, France, Italy, United } \\
\text { Kingdom, Germany, Denmark, } \\
\text { Austria, Luxembourg) }\end{array}$ & $\begin{array}{c}\text { II } \\
\text { (Bulgaria, Slovakia, Finland, } \\
\text { Greece, Latvia, Estonia) }\end{array}$ & $\begin{array}{c}\text { III } \\
\text { (Czechia, Slovenia, Ireland, } \\
\text { Lithuania, Portugal, } \\
\text { Hungary, Poland, Croatia, } \\
\text { Romania, Cyprus, Malta) }\end{array}$ \\
\hline 2013 & 1.6 & 4 & $\begin{array}{c}\text { I } \\
\text { (Belgium, Netherlands, Denmark, } \\
\text { Austria, Luxembourg, Finland) } \\
\text { II } \\
\text { (Germany, Spain, France, Italy, } \\
\text { United Kingdom) }\end{array}$ & $\begin{array}{c}\text { IV } \\
\text { (Ireland, Greece, Cyprus, } \\
\text { Croatia, Malta) }\end{array}$ & $\begin{array}{c}\text { III } \\
\text { (Bulgaria, Portugal, } \\
\text { Sweden, Czechia, Slovakia, } \\
\text { Estonia, Slovenia, Latvia, } \\
\text { Lithuania, Hungary, } \\
\text { Romania, Poland) }\end{array}$ \\
\hline 2014 & 2.4 & 3 & $\begin{array}{c}\text { I } \\
\text { (Belgium, Netherlands, Spain, } \\
\text { France, Italy, United Kingdom, } \\
\text { Germany) }\end{array}$ & $\begin{array}{c}\text { II } \\
\text { (Bulgaria, Estonia, Greece, } \\
\text { Cyprus, Croatia, Hungary, } \\
\text { Romania, Slovakia, Latvia, } \\
\text { Malta) }\end{array}$ & $\begin{array}{c}\text { III } \\
\text { (Czechia, Slovenia, Poland, } \\
\text { Ireland, Portugal, Finland, } \\
\text { Lithuania, Sweden, } \\
\text { Denmark, Luxembourg, } \\
\text { Austria) }\end{array}$ \\
\hline 2015 & 1.85 & 4 & $\begin{array}{c}\text { I } \\
\text { (Belgium, Netherlands, Denmark, } \\
\text { Austria, Luxembourg) } \\
\text { II } \\
\text { (Germany, Spain, France, Italy, } \\
\text { United Kingdom) }\end{array}$ & $\begin{array}{c}\text { IV } \\
\text { (Greece, Cyprus, Malta, Ireland) }\end{array}$ & $\begin{array}{l}\text { III } \\
\text { (Bulgaria, Lithuania, } \\
\text { Finland, Portugal, Slovenia, } \\
\text { Sweden, Czechia, Croatia, } \\
\text { Slovakia, Romania, Estonia, } \\
\text { Latvia, Hungary, Poland) }\end{array}$ \\
\hline 2016 & 1.7 & 5 & $\begin{array}{c}\text { I } \\
\text { (Germany, Belgium, Netherlands, } \\
\text { Spain, France, Italy, } \\
\text { United Kingdom) } \\
\text { II } \\
\text { (Denmark, Austria Luxembourg, } \\
\text { Lithuania, Slovenia) }\end{array}$ & $\begin{array}{c}\text { V } \\
\text { (Greece, Cyprus, Malta, Latvia) }\end{array}$ & $\begin{array}{c}\text { III } \\
\text { (Bulgaria, Estonia) } \\
\text { IV } \\
\text { (Czechia Slovakia, } \\
\text { Romania, Croatia, Hungary, } \\
\text { Poland, Ireland, Finland, } \\
\text { Portugal, Sweden) }\end{array}$ \\
\hline 2017 & 1.5 & 4 & $\begin{array}{c}\text { II } \\
\text { (Germany, Spain, France, Italy, } \\
\text { Netherlands) }\end{array}$ & $\begin{array}{c}\text { IV } \\
\text { (Greece, Cyprus, Romania, } \\
\text { Malta, Portugal) }\end{array}$ & $\begin{array}{c}\text { I } \\
\text { (Belgium, United Kingdom, } \\
\text { Ireland, Finland, Lithuania, } \\
\text { Slovenia, Sweden, } \\
\text { Denmark, Austria, } \\
\text { Luxembourg) } \\
\text { III } \\
\text { (Bulgaria, Estonia, Croatia, } \\
\text { Czechia, Slovakia, Latvia, } \\
\text { Hungary, Poland) }\end{array}$ \\
\hline 2018 & 1.5 & 4 & $\begin{array}{c}\text { II } \\
\text { (Germany, Spain, Netherlands) }\end{array}$ & $\begin{array}{c}\text { IV } \\
\text { (Greece, Cyprus, Malta, Ireland) }\end{array}$ & $\begin{array}{c}\text { I } \\
\text { (Belgium, Sweden, France, } \\
\text { Italy, Portugal, Slovenia, } \\
\text { Finland, United Kingdom, } \\
\text { Denmark, Lithuania, } \\
\text { Austria, Luxembourg) } \\
\text { III } \\
\text { (Bulgaria, Estonia, Latvia, } \\
\text { Croatia, Czechia, Hungary, } \\
\text { Poland, Slovakia, Romania) }\end{array}$ \\
\hline
\end{tabular}


All results obtained by means of a cluster analysis confirm the data included in Tables 2 and 3, calculated according to linear ordering on the basis of the Hellwig algorithm.

In a further analysis, the significance of trends for the development indicators of the analysed countries in 2010-2018 was verified. The analysis allowed the investigators to establish significant growing trends for IDCE only in the case of two countries, i.e., Belgium and the Netherlands at significance level $\alpha=0.1$, while no significant trends were established for the other countries (Figure 1).

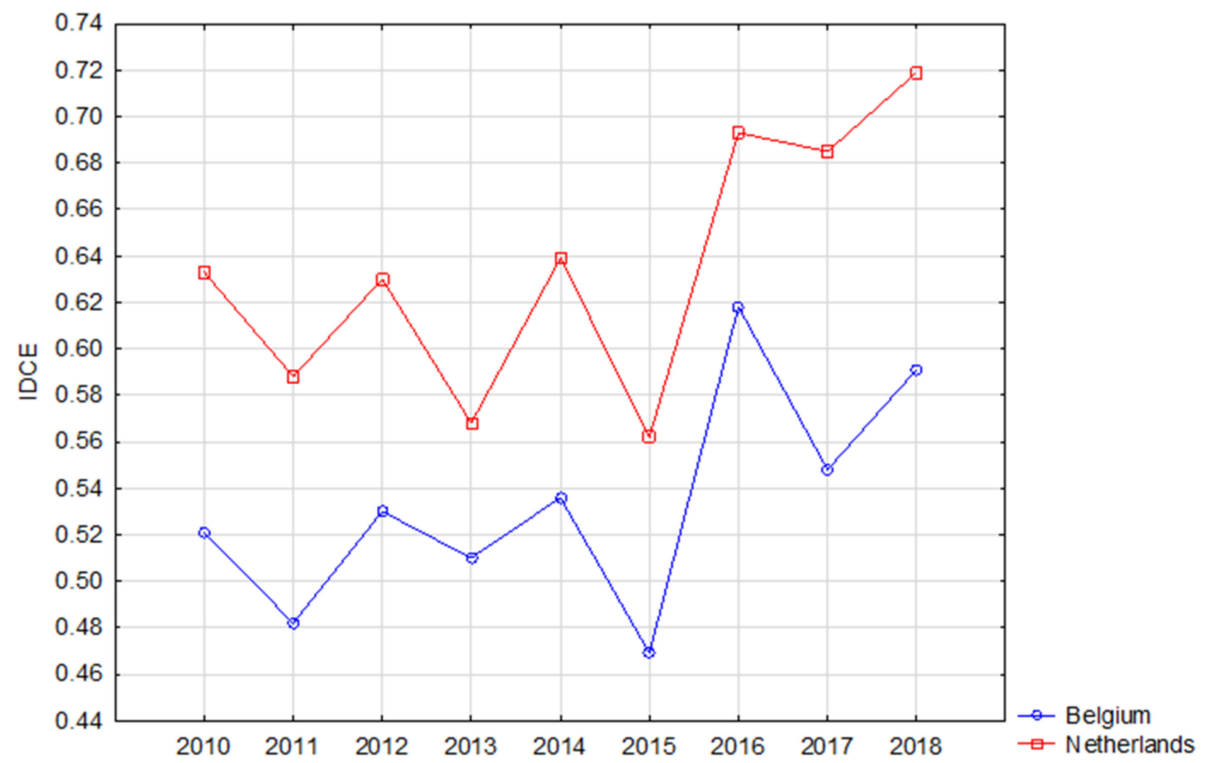

Figure 1. Line graph for the IDCE synthetic variables for the Netherlands and Belgium in 2010-2018. Source: author's compilation.

This is confirmed by calculations included in Tables 5 and 6, which comprise a summary of the analysed regressions.

An analysis of Table 5 results allows a conclusion as to the significance of the analysed trend $p<0.096$ at the adopted significance level alpha $=0.1$. With each subsequent year, the development indicator goes up by 0.010 .

Table 5. Summary of regression of dependent variable: Belgium.

$R=0.58 R^{\wedge} 2=0.34$ Adjusted Coefficient of Determination R2 $=0.25$

$F(1.7)=3.67 p<0.096$ Standard Error of Estimate: 0.04

\begin{tabular}{ccccccc}
$n=9$ & $\mathbf{b}^{*}$ & $\begin{array}{c}\text { Standard Error of } \\
\text { Coefficient } \mathbf{b}^{*}\end{array}$ & $\mathbf{b}$ & Standard Error of $\mathbf{b}$ & $\mathbf{t}(7)$ & $\boldsymbol{p}$ \\
\hline Intercept & & & -20.042 & 10.735 & -1.867 & 0.104 \\
\hline Year & 0.587 & 0.306 & 0.010 & 0.005 & 1.917 & 0.097 \\
\hline
\end{tabular}

Source: author's compilation. Source: as in Table 2.

Table 6. Summary of regression of dependent variable: Netherlands.

$R=0.61 R^{\wedge} 2=0.38$ Adjusted Coefficient of Determination $R 2=0.29$

$F(1.7)=4.2930 p<0.7700$ Standard Error of Estimate: 0.047

\begin{tabular}{ccccccc}
$n=9$ & \multicolumn{1}{c}{$\mathbf{b}^{*}$} & $\begin{array}{c}\text { Standard Error of } \\
\text { Coefficient } \mathbf{b}^{*}\end{array}$ & $\mathbf{b}$ & Standard Error of $\mathbf{b}$ & $\mathbf{t}(7)$ & $\boldsymbol{p}$ \\
\hline Intercept & & & -24.708 & 12.231 & -2.020 & 0.083 \\
\hline Year & 0.617 & 0.298 & 0.013 & 0.006 & 2.072 & 0.083 \\
\hline
\end{tabular}

Source: author's compilation. Source: as in Table 2. 
An analysis of Table 6 results allows a conclusion about the significance of the analysed trend $p<0.096$ at the adopted significance level alpha $=0.1$. With each subsequent year, the development indicator goes up by 0.013 .

On the basis of the analyses (information included in Tables 3, 5 and 6), it may be concluded that the greatest progress in terms of improving the result (an increase in the IDCE synthetic variables) was achieved by the Netherlands and Belgium.

To conclude: The analysis shows that among all EU countries, the countries of the "old European Union" (EU-15) are in the majority of cases the most advanced in their pursuit towards $C E$ and it is the states from this group that take top positions in the IDCE ranking.

Among them, the following are in the lead: Germany, Belgium, the Netherlands, and also Spain, France, Italy and the United Kingdom, whereas against this background, the weakest results are obtained by Portugal, Ireland and Greece, who occupies one of the lowest positions in the period investigated.

The countries which joined the EU after 2004 (EU-13) are less advanced in their pursuit of CE compared to the EU-15.

Among all 28 investigated EU countries, Malta, Cyprus, Croatia, Latvia and the already mentioned Greece and Ireland are the least advanced in their pursuit of CE.

The research shows the existing disproportions among the European countries in terms of their results in the field of progress towards CE. While most EU-15 countries obtained high results and are at the top of the CE ranking, new EU members mainly still need to improve their macroeconomic $\mathrm{CE}$ indicators.

Rising trends for the IDCE among the EU countries were only observed for Belgium and The Netherlands. One of the reasons may be that densely populated industrialised countries seem to attribute greater weight to effective use of raw materials and circular material use. As a result of actions taken, they are often in the lead of countries that apply institutionalised solutions relating to circular economy.

It needs to be emphasised that the analysis was performed on the basis of indicators selected among those that were included in the CE monitoring framework. Therefore, relatively few indicators were used to build the IDCE index (carefully selected and compliant with scientific standards), mainly those relating to "waste". However, it is worth pointing to another ranking of European countries (26 states) in the course of the discussion. It was drawn up on the basis of results for, inter alia, CE [89]. A more extensive set of indicators was used to compile it, which resulted from other methodological assumptions and goals adopted by the researchers. They focus on presenting a holistic approach to measuring countries' performance in managing and exploiting their Municipal Solid Waste (MSW). In the course of their research, the investigators found Belgium to have the best CE-related results among the European countries. This confirms results of the research presented in this paper where Belgium is one of the top countries in terms of CE implementation according to the IDCE, and it is one of the two countries that reported rising trends for IDCE.

The investigator concluded in the course of the research that the differences in terms of CE implementation between some countries of Central and Eastern Europe and of Western Europe are decreasing (on the basis of the IDCE ranking). Despite the fact that throughout the investigated period top places in the IDCE-based ranking of EU countries in terms of their progress towards CE are taken by the EU-15 states, there is still noticeable improvement among some of the EU-13, inter alia Lithuania, Poland or Slovenia. The authors of the previously mentioned research came to similar conclusions [89]. They demonstrated [89] in their analysis that CE-related results of some EU-15 countries, such as France or Spain, are worse than those of countries of Central and Eastern Europe, e.g., Poland. However, the research carried out in this paper does not confirm this for those countries.

An analysis of CE indicators for EU Member States may in the future turn out to be a relevant method to identify leaders in $\mathrm{CE}$ implementation.

Some EU countries, especially those which, as the research has shown, are most advanced in their pursuit towards $\mathrm{CE}$, had implemented national regulations and programs 
concerning the CE subject matter even before the European Commission created the EU framework and guidelines on transitioning to circular economy. For example, Germany set a goal to separate economic growth and material use from 2002 onwards; in 2012, it adopted a statute which expressly promotes circular economy and material loops. Since 2000, Great Britain has been developing an initiative that promotes circular economy called WRAP (Waste and Resources Action Plan), which in recent years has been oriented more strongly towards a global approach to CE. In turn, France in 2013 developed an action plan for its transition to circular economy and created the French Circular Economy Institute. It is also important that countries with the best results of advancement towards $\mathrm{CE}$ have well-functioning recycling systems and feature a high level of innovation in circular economy sectors.

In some of these countries, e.g., Germany, Great Britain or Austria, the improvement of the use of raw materials is considered one of political targets, which is an essential CE element [122]. What is more, Germany, Finland and Austria have an already-developed strategy dedicated to resource-efficiency [123]. The German resource-efficiency strategy is considered to be a pioneer method, and this country has begun to use roadmap concepts within a sectoral approach [124]. It needs to be noted that most EU Member States address resource-efficiency issues in one or a few strategies and action plans $[10,124]$.

The analysis performed in this paper shows that few countries changed their positions significantly in the ranking in some of the investigated years. This is true, inter alia, for Finland. This is determined by the data reported included in the statistics taken into account when constructing the IDCE indicator. Finland took up enhanced actions at the beginning of the first decade of the 21st century (compared to other European countries), mainly in the area of green public procurement, sustainable consumption and production (Programme to Promote Sustainable Consumption and Production (2005)) and "intelligent use of natural resources" (Natural Resources Strategy: Using Resources Intelligently (2009)). This country wants to be a CE leader, which is evidenced by its efforts and the adopted documents, such as: National Material Efficiency Programme 2014, Finnish Road Map to a Circular Economy 2016-2025; The Critical Move: Finland's Roadmap to the Circular Economy 2.0, national waste management plan Towards a Recycling Society—the National Waste Plan for 2016 or national waste management plan From Recycling to a Circular Economy-National Waste Plan to 2023-2017. However, as pointed out by O. Fitch-Roy et al. [125], the Finnish Road Map to a Circular Economy 2016-2025 and its updated revision (The Critical Move: Finland's Roadmap to the Circular Economy 2.0) fail to present greater coherence with national economic and industrial policy and fail to refer to related strategic documents, e.g., From Recycling to a Circular Economy-National Waste Plan to 2023-2017 (Finland's Road Map does not directly refer to the hierarchy in dealing with waste). This may result in certain future incoherence in main CE-related documentation. It is a valuable observation also for other countries that are on their path towards CE. Since 2016, Finland has been intensifying its activity to implement $\mathrm{CE}$, wishing to become a future leader. From the perspective of the IDCE indicator, it is important whether it will intensify its activities in areas that are strongly represented in its construction.

A new trend that appeared among the EU countries is the impact of circular economy principles on a country's strategic direction. Some EU countries have already adopted such strategic packages that support circular economy principles, for example, Denmark (Strategy for the Circular Economy-2018), Greece (National Circular Economy Strategy, National Action Plan on Circular Economy 2018, 2019), Finland (Leading the cycle: Finnish Road Map to a Circular Economy 2016-2025; The Critical Move: Finland's Roadmap to the Circular Economy 2.0), the Netherlands (Circular Economy Programme (A Circular Economy in the Netherlands by 2050 2016)), Italy (Towards a Circular Economy Model for Italy - Overview and Strategic Framework), Slovenia (Roadmap towards the Circular Economy in Slovenia 2018) or Poland (Roadmap towards the Transition to the Circular Economy 2019). They include Greece, which took a low position in the ranking compiled in Table 3 . This results mainly from the fact that for years this country has had problems with 
implementing waste management policies (in 2004, the European Court of Justice (ECJ) declared that Greece violated obligations resulting from the EU Waste Framework Directive to close landfill sites - judgment of 24 June 2004, Commission v Greece (C-119/02, not published, EU:C:2004:385); the EC claimed that the Court should declare that the Hellenic Republic had failed to fulfil its obligations under Article 260(1) TFEU)" [126]), and in 2015 the European Commission reported Greece to the ECJ for "persistent poor waste water treatment" [127]. The National Action Plan on Circular Economy in 2018 and National Plan for Waste Management 2015-2030 adopted by Greece are intended to help it tackle the "waste" programme, though noticeable progress in this regard is still to be seen.

When reviewing national Member States' CE programmes, policies and strategies, one can see that the great majority of targets included in them address the recycling and reuse of materials, which is intended to increase the contribution of waste management in the circular economy. This may result from the fact that waste management was one of the main environmental problems reported by the EU countries [124]. The great majority of Member States showed the need to improve waste management (26 countries in 2018 [124] and 12 countries in 2015 [10]). Unfortunately, only a few noted the need to increase the use of secondary raw materials and to close material loops, which is indeed CE's essence. It may be presumed that attributing such a high rank to waste management by some Member States results from specific goals defined in the EU legislation that address recycling and reuse and from the significance of "waste as a resource" for effective waste management and for the CE. Other goals established in the framework of national CE policies and programmes concern increasing the share of recycled and reused materials, introducing new business models for reuse, refurbishment and remanufacturing, improving CE communication and education and reducing greenhouse gas emissions (France even included a circular economy action plan in its act on energetic transformation for green growth).

Unfortunately, a large share of strategies and plans of individual EU countries concerning CE do not specify their goals measurably. The exceptions here are inter alia the Dutch government-wide programme for a circular economy by 2015 (it includes a quantitative goal of a $50 \%$ reduction in the use of primary raw materials (minerals, fossil and metals) by 2030) and the French circular economy action plan, which aims to reduce French material consumption-domestic material consumption (DMC)/gross domestic product (GDP) - by $30 \%$ by 2030 compared to 2010 [124].

An analysis of national CE documents points to a great differentiation of their scope and complexity. For countries that adopted such documents early, the policy framework is quite extensive and accommodates mutually strengthening initiatives that support the circular economy [128]. It is noticeable that most EU Member States include resourceefficiency and circular economy under other policies. Very often these are policies on waste (e.g., in 2017 Finland included CE goals in its national waste management plan From recycling to a circular economy-National Waste Plan to 2023-(2017)), and some countries adopt relevant dedicated documents, e.g., Belgium - Implementation Plan on Household Waste and Comparable Industrial Waste (2016-2022), Netherlands-Third National Waste Management Plan 2017. This may result from the fact that four legislative initiatives on waste were associated with the 2015 EU circular economy action plan. Directing the EU towards energy efficiency and climate change causes the relevant policies to also include elements of resource-efficiency and circular economy (Belgium (Walloon Region), Estonia, France or Latvia). The EU political agenda has been placing growing emphasis on a synergy between biological economics and circular economy, and some EU countries have already developed strategies for a green economy/green growth/green jobs (e.g., France-A Bioeconomy Strategy for France: 2018-2020 Action plan). Issues of material resource-efficiency and circular economy have been surfacing or are more emphasised in new or amended sustainable development strategies (e.g., Finland-Strategy for Sustainable Development "Finland We Want" 2050, France- the National Sustainable Development Strategy for 20202030, Germany—Sustainable Development Strategy 2016, Italy-The National Strategy for Sustainable Development 2017, Law No 221/2015 Environment Provisions to Pro- 
mote Green Economy Measures and Contain Excessive Use of Natural Resources 2015, Poland-Strategy for Responsible Development (SRD) by 2020 (with a perspective to 2030), Slovenia-Vision for Slovenia in 2050 and the 2030 Slovenian Development Strategy-2017) or framework eco programmes (Germany-Integrated environmental programme 2030, Shaping Ecological Transformation 2016, Slovakia-Strategy of the Environmental Policy of the Slovak Republic until 2030).

From the factual perspective and from the perspective of real $\mathrm{CE}$ implementation, it is important to look closely at policies of individual counties and also at effects and at the achievement of $\mathrm{CE}$ goals both in relevant strategies and programmes and unrelated policies that include $\mathrm{CE}$ aspects. One must see whether these documents only include "nicely formulated principles" or whether well-developed goals and actions included in programmes and policies, etc., intended to implement CE in individual countries are actually pursued [112]. Monitoring CE gains significance in this context. The possibility to compare counties and to classify them in terms of CE implementation seems important.

One needs to bear in mind that each country in the EU has its own specifics that lead to different approaches and set different time frames for transitioning to circular economy. Some EU countries (i.e., countries of Central and Eastern Europe) have officially adopted an obligation to transform their economies in accordance with the CE idea, whereas despite the legislative activity carried out and other initiatives taken in this scope, some of them are only at the initial phase of implementation.

It is necessary for them to take up further legislative activities, new social initiatives and new technological solutions in terms of, e.g., eco-innovation, in order to speed up this process. EU support, both in terms of creating uniform guidelines and financing adequate initiatives, is particularly important to these countries.

A literature review shows that the application of direct financial incentives and support programmes for resource-efficiency in different Member States (also at the level of companies) is similar in terms of instruments employed and the effects they have. However, there is no single universal instrument applied in all Member States. Combinations of innovations in resource and technology efficiency are proving compelling and drive market incentives programmes and information transfer [129].

The 2019 EEA report [124] shows that among all investigated countries only Germany, Italy and the Netherlands pointed to the availability of national programmes for financing eco-innovations to promote clean technologies and materials and energy-efficient products and production processes as a driving force, that is, programmes that are a real reflection of $\mathrm{CE}$ implementation. These are countries that were in the top positions in the Table 2 ranking.

Member States are active in creating programmes and institutions for CE, but there are also areas that require improvement and specific and real action. They include ecoinnovations, environmental taxes or removing subsidies that are harmful to the environment in sectors that require substantial resources. The countries of Central and Eastern Europe and of Southern Europe have the most to do in this regard.

Expanding the EU to include the countries of Central and Eastern Europe, which have weak environmental frameworks, increased the discrepancies between countries both in adopting and implementing the common EU legal frameworks. This has undoubtedly had an impact on resource-efficiency and CE. There are still significant differences in results and prevailing policy frameworks. This is confirmed in the research conducted in this study. According to some researchers, increasing disproportions between the EU countries with the best and the worst results in implementing CE may provide encouragement for slowly developing Member States or those that operate the poorest in this regard to intensify their efforts to improve their national strategies. Thus, they secure certain benefits "resulting from being top of the list" to CE leaders in the EU.

It may also be assumed that different approaches to $C E$ taken by the EU countries and a different level of implementation of this concept have their basis inter alia in legal and political determinants and result from the absence of a direction in the transformation 
into a resource-efficient circular economy. This may be grounded inter alia in partially inconsistent or incomplete guidelines at the European level, in the coordination of interests of stakeholders and the industry at the national level. One solution may be to clearly combine resource-efficiency policies and circular economy policies, and to approximate their interrelations, starting from the EU level. One must also note that the literature boasts a growing number of research on CE-related regulations, yet analyses of the optimal model of CE policy packages are still few and far between [125].

On the basis of analyses, reports or documents presented in the literature, the assumption could be made that the disproportion between individual countries in terms of their transformation towards $\mathrm{CE}$ will continue for the next few years. One may hope that due to the emerging (as well as planned and prepared) documents of the European Commission concerning CE and CE documents and strategies of individual countries, the transformation of EU countries towards CE will be more dynamic. However, in order for this to happen, it is necessary (apart from the above-mentioned issues) to take actions intended to increase CE awareness.

\section{Conclusions}

The circular economy model facilitates resignation from the currently dominant predatory model of linear economy, based on the "take, make, consume, dispose" model. CE assumes the closing of the loop, which eliminates the "dispose" stage and replaces it with "reuse". CE principles need to be applied at each stage of product life, starting from design, to production and consumption, to waste management. Various kinds of legal acts, guidelines and requirements or tools and programs for financing relevant initiatives are helpful in implementing these principles. Transformation towards CE may be implemented at various levels, i.e., macro, meso and micro. However, the path to a full transformation of the economy into circular economy requires time and extensive outlays.

The European Union plays an essential role in disseminating CE principles. The European Commission has published a number of documents on CE, in which inter alia it obliged Member States to carry out processes associated with transforming their economies into circular economy. It also highlighted in these documents the CE monitoring aspect through the creation of the so-called monitoring framework. It is essential to be able to, among other things, compare Member States in terms of their progress in transitioning to circular economy. This allows one to identify leaders, and also on the basis of their experience to develop good practices that serve other Member States that are less advanced in their transition to CE.

The subject matter of measuring CE, especially at the macro level, is covered by scholarly studies. However, there are still areas in said subject matter that are worth filling, so-called research gaps. Given the above, the assessment of the level of progress towards circular economy of Member States of the European Union in 2010-2018 was adopted as the purpose of this paper. In order to implement the circular economy, apart from a critical literature analysis, a comparative analysis (research) was performed, which expanded our knowledge on EU Member States' progress towards CE and allowed a look at measuring $\mathrm{CE}$ in the EU countries from a fresh perspective.

After a critical CE literature review, looking closely at the macro level, a decision was made to choose indicators that were selected by the European Commission for $\mathrm{CE}$ monitoring in the EU. The IDCE synthetic indicator built on their basis facilitated comparisons between EU countries as to the level of their advancement towards CE. Thanks to the application of statistical methods, a ranking of countries in terms of the level of their progress towards $C E$ was compiled, followed by grouping them and verifying significant trends for the IDCE synthetic variables of the analysed countries in 2010-2018.

In order to ensure the easiest operability of indicators, all of those suggested in the analysis were of a quantitative nature.

On the basis of this analysis, it was concluded that among all EU countries, those of the old EU (EU-15) are the most advanced in terms of CE, especially Germany, Belgium, 
The Netherlands, but also Spain, France, Italy and the United Kingdom. In turn, the countries least advanced in their pursuit towards CE include mainly Malta, Cyprus, Croatia, Latvia as well as Ireland and Greece. The analysis confirmed significant rising trends for IDCE only in the case of two countries, Belgium and the Netherlands.

Such differentiated levels of advancement of individual countries towards CE result inter alia from the adoption by some of the latter of different development strategies for their economies' transition to circular economy (according to recommendations of EU ministers at the Environment Council in June 2016) and also from the differences occurring in social and economic development (it is mostly noticeable between the EU-15 and the EU-13 countries). Unfortunately, as can be concluded from the effects obtained so far, only a few of the adopted development strategies may be considered as effective in meeting the challenges of circular economy according to the European Union's standards. The author is aware of the limitations of this paper, mainly: the length of the research period (determined by the availability of data) and resignation from additionally adopting qualitative indicators.

The analysis carried out in this paper may be further developed by, i.e., expanding the analysed time frame (according to available data), selecting other indicators, applying other statistical methods or constructing econometric models.

It is recommended that further research should investigate whether EU countries generally are capable of transitioning to circular economy and in what timeframe they are able to do so. In the light of the content presented, some questions arise that are worth looking for answers for, e.g., What should the EU countries' transition to circular economy look like exactly? What paths need to be taken so as to transform the economies of EU countries into circular economies? What social and institutional changes in terms of consumption and production methods will this require? What should particular emphasis be placed on when transitioning towards CE? What role should technological innovations play? In what direction should further modification of the CE monitoring framework go? Searching for answers to these questions is a starting point for further scholarly research and studies that can expand our knowledge of $\mathrm{CE}$.

Funding: This paper is financed within the framework of the program of the Minister of Science and Higher Education under the name "Regional Excellence Initiative" in the years 2019-2022; project number 001/RID/2018/19.

Institutional Review Board Statement: Not applicable.

Informed Consent Statement: Not applicable.

Data Availability Statement: https:/ / ec.europa.eu/eurostat/data/database; https:/ / ec.europa.eu /eurostat/cache/scoreboards/CE_DataBro/index.html (accessed on 10 September 2020).

Conflicts of Interest: The author declares no conflict of interest.

\section{References}

1. Stahel, W.R. The circular economy. Nature 2016, 531, 435-438. [CrossRef] [PubMed]

2. Merli, R.; Preziosi, M.; Acampora, A. How do scholars approach the circular economy? A systematic literature review. J. Clean. Prod. 2018, 178, 703-722. [CrossRef]

3. Korhonen, J.; Honkasalo, A.; Seppälä, J. Circular economy: The concept and its limitations. Ecol. Econ. 2018, 143, 37-46. [CrossRef]

4. Lakatos, E.S.; Cioca, L.-I.; Dan, V.; Ciomos, A.O.; Crisan, O.A.; Barsan, G. Studies and investigation about the attitude towards sustainable production, consumption and waste generation in line with circular economy in Romania. Sustainability 2018, 10, 865. [CrossRef]

5. D'Amato, D.; Droste, N.; Allen, B.; Kettunen, M.; Lahtinen, K.; Korhonen, J.; Leskinen, P.; Matthies, B.; Toppinen, B. Green, circular, bio economy: A comparative analysis of sustainability avenues. J. Clean. Prod. 2017, 168, 716-734. [CrossRef]

6. Sariatli, F. Linear economy versus circular economy: A comparative and analyzer study for optimization of economy for sustainability. Visegr. J. Bioecon. Sustain. Dev. 2017, 6, 31-34. [CrossRef]

7. Wastling, T.; Charnley, F.; Moreno, M. Design for circular behaviour: Considering users in a circular economy. Sustainability 2018, 10, 1743. [CrossRef] 
8. Boulding, K.E. The economics of the coming spaceship earth. In Environmental Quality Issues in a Growing Economy; Jarrett, H., Ed.; Johns Hopkins University Press: Baltimore, MD, USA, 1966; pp. 3-14.

9. Geissdoerfer, M.; Savaget, P.; Bocken, N.M.P.; Hultink, E.J. The Circular Economy-A new sustainability paradigm? J. Clean. Prod. 2017, 143, 757-768. [CrossRef]

10. European Environmental Agency (EEA). Circular Economy in Europe. Developing the Knowledge Base; European Environmental Agency Report No 2/2016; Publications Office of the European Union: Luxembourg, 2016.

11. Cheng, M. Sharing economy: A review and agenda for future research. Int. J. Hosp. Manag. 2016, 57, 60-70. [CrossRef]

12. Habibi, M.R.; Davidson, A.; Laroche, M. What managers should know about the sharing economy. Bus. Horiz. $2017,60,113-121$. [CrossRef]

13. Stahel, W. The product life factor. In An Inquiry into the Nature of Sustainable Societies. The Role of the Private Sector; Orr, G.S., Ed.; Houston Area Research Centre: Houston, TX, USA, 1982; pp. 72-105.

14. Commission of European Communities. Closing the Loop-An EU Action Plan for the Circular Economy; Communication No. 614; (COM (2015), 614); Commission of European Communities: Brussels, Belgium, 2015; Available online: https:/ / eur-lex.europa.eu/ resource.html?uri=cellar:8a8ef5e8-99a0-11e5-b3b7-01aa75ed71a1.0012.02/DOC_1\&format=PDF (accessed on 20 November 2020).

15. Commission of European Communities. Towards a Circular Economy: A Zero Waste Programme for Europe; Communication No. 398; (COM (2014), 398); Commission of European Communities: Brussels, Belgium, 2014; Available online: http:/ / ec.europa.eu/envir onment/circular-economy/pdf/ circular-economy-communication.Pdf (accessed on 20 November 2020).

16. Karwacka, M.; Łuba, P. W Kierunku Gospodarki Obiegu Zamkniętego: Wyzwania i Szanse; Koalicja na Rzecz Gospodarki Obiegu Zamkniętego: Warszawa, Poland, 2016.

17. European Academies' Science Advisory Council. Indicators for a Circular Economy; European Academies' Science Advisory Council: Halle, Germany, 2016.

18. Geng, Y.; Fu, J.; Sarkis, J.; Xue, B. Towards a national circular economy indicator system in China: An evaluation and critical analysis. J. Clean. Prod. 2012, 23, 216-224. [CrossRef]

19. Oswald, I. Environmental Metrics for WEEE Collection and Recycling Programs; Universitat Augsburg, Institut für Materials Ressource Management (MRM): Augsburg, Germany, 2013.

20. European Commission. Measuring Progress Towards Circular Economy in the European Union-Key Indicators for a Monitoring Framework; European Commission: Strasbourg, France, 2018.

21. OECD. Green Growth Indicators 2017; OECD: Paris, France, 2017.

22. World Bank. The Little Green Data Book 2017. World Development Indicators; World Bank: Washington, DC, USA, 2017.

23. WBCSD. CEO Guide to the Circular Economy. 2017. Available online: www.wbcsd.org/Clusters/CircularEconomy/Resources /CEO-Guide-to-the-Circular-Economy (accessed on 10 January 2020).

24. Ellen MacArthur Foundation (EMF). Towards the Circular Economy 1: An Economic and Business Rationale for an Accelerated Transition. 2012. Available online: https://www.ellenmacarthurfoundation.org/assets/downloads/publications/Ellen-Mac Arthur-Foundation-Towards-the-Circular-Economy-vol.1.pdf (accessed on 20 November 2020).

25. Ellen MacArthur Foundation (EMF). Towards the Circular Economy: Opportunities for the Consumer Goods Sector. 2013. Available online: https://www.ellenmacarthurfoundation.org/assets/downloads/publications/TCE_Report-2013.pdf (accessed on 30 June 2020).

26. Ellen MacArthur Foundation (EMF). Circular Indicators: An approach to measuring circularity. Methodology 2015. [CrossRef]

27. Ellen MacArthur Foundation (EMF). Delivering the Circular Economy: A Toolkit for Policymakers. 2015. Available online: https: / / www.ellenmacarthurfoundation.org/assets / downloads/publications/EllenMacArthurFoundation_PolicymakerToolkit.pdf (accessed on 20 November 2020).

28. Wu, H.-Q.; Shi, Y.; Xia, Q.; Zhu, W.-D. Efectiveness of the policy of circular economy in China: A DEA-based analysis for the period of 11th five-year-plan. Resour. Conserv. Recycl. 2014, 83, 163-175. [CrossRef]

29. Su, B.; Heshmati, A.; Geng, Y.; Yu, X. A review of the circular economy in China: Moving from rhetoric to implementation. J. Clean. Prod. 2013, 42, 215-227. [CrossRef]

30. Fan, Y.; Fang, C. Circular economy development in China-Current situation, evaluation and policy implications. Environ. Impact Assess. Rev. 2020, 84, 106441. [CrossRef]

31. Potting, J.; Hekkert, M.; Worrell, E.; Hanemaaijer, A. Circular Economy: Measuring Innovation in Product Chains; PBL Netherlands Environmental Assessment Agency: The Hague, The Netherlands, 2017.

32. Potting, J.; Hanemaaijer, A. Circular Economy: What We Want to Know and Can Measure. Framework and Baseline Assessment for Monitoring the Progress of the Circular Economy in the Netherlands; PBL Netherlands Environmental Assessment Agency: The Hague, The Netherlands, 2018.

33. Dutch Ministry of Environment. A Circular Economy in the Netherlands by 2050. 2016. Available online: https://www.oecd.org / environment/ministerial/whatsnew / 2016-ENV-Ministerial-Netherlands-Circulareconomy-in-the-Netherlands-by-2050.pdf (accessed on 14 October 2018).

34. Magnier, C.; Auzanneau, M.; Calatayud, P.; Gauche, M.; Ghewy, X.; Granger, M.; Margontier, S.; Pautard, E. 10 Key Indicators for Monitoring the Circular Economy, The Monitoring and Statistics Directorate. France 2017. Available online: http:/ / temis.documentation.developpement-durable.gouv.fr/docs/Temis/0086/Temis-0086452/22978_2017_ENG.pdf (accessed on 20 November 2020). 
35. The French Ministry of Ecological and Solidarity Transition. France Unveils Circular Economy Roadmap. 2018. Available online: https:/ / www.ecologique-solidaire.gouv.fr/sites/default/files/FREC\%20-\%20EN.pdf (accessed on 28 June 2020).

36. Towards a Model of Circular Economy for Italy-Overview and Strategic Framework. Ministry for the 961 Environment, Land and Sea Ministry of Economic Development 2017. Available online: https:/ / circulareconomy.europa.eu/platform/sites/default / files/strategy-towards_a_model_eng_completo.pdf (accessed on 26 June 2020).

37. Ghisellini, P.; Ulgiati, S. Circular economy transition in Italy. Achievements, perspectives and constraints. J. Clean. Prod. 2019, 243, 118360. [CrossRef]

38. Ministry of Environment of Portugal. Leading the Transition: A Circular Economy Action Plan for Portugal: 2017-2020. 2017. Available online: https:/ / circulareconomy.europa.eu/platform/sites/default/files/strategy-portuguese_action_plan_paec_en _version_3.pdf (accessed on 16 June 2020).

39. Rantaa, V.; Aarikka-Stenroosa, L.; Ritalab, P.; Mäkinena, S.J. Exploring institutional drivers and barriers of the circular economy: A cross regional comparison of China, the US, and Europe. Resour. Conserv. Recycl. 2017, 135, 70-82. [CrossRef]

40. Prieto-Sandoval, V.; Jaca, C.; Ormazabal, M. Towards a consensus on the circular economy. J. Clean. Prod. 2018, 179, 605-615. [CrossRef]

41. Elia, V.; Gnoni, M.G.; Tornese, F. Measuring circular economy strategies through index methods: A critical analysis. J. Clean. Prod. 2017, 142, 2741-2751. [CrossRef]

42. Iacovidou, E.; Velis, C.A.; Purnell, P.; Zwirner, O.; Brown, A.; Hahladakis, J.; Millward-Hopkins, J.; Williams, P.T. Metrics for optimising the multi-dimensional value of resources recovered from waste in a circular economy: A critical review. J. Clean. Prod. 2017, 166, 910-938. [CrossRef]

43. Sánchez-Ortiz, J.; Rodríguez-Cornejo, V.; Río-Sánchez, R.D.; García-Valderrama, T. Indicators to Measure Efficiency in Circular Economies. Sustainability 2020, 12, 4483. [CrossRef]

44. Silvestri, F.; Spigarelli, F.; Tassinari, M. Regional development of Circular Economy in the European Union: A multidimensional analysis. J. Clean. Prod. 2020, 255, 120218. [CrossRef]

45. Di Maio, F.; Rem, P.C. A robust indicator for promoting circular economy through recycling. J. Environ. Prot. 2015, 6, 1095-1104. [CrossRef]

46. Zarbà, C.; La Via, G.; Pappalardo, G.; Hamam Manal Samir, M. The sustainability of Novel foods in the transition phase to the circular economy; the trade "Algae fit for human consumption" in European Union. AIMS Agric. Food 2020, 5, 54-75. [CrossRef]

47. Bigano, A.; Śniegocki, A.; Zotti, J. Policies for a more dematerialized EU economy. Theoretical underpinnings, political context and expected feasibility. Sustainability 2016, 8, 717. [CrossRef]

48. Marino, A.; Pariso, P. Comparing European countries' performances in the transition towards the Circular Economy. Sci. Total Environ. 2020, 729, 138142. [CrossRef] [PubMed]

49. Kasztelan, A. How circular are the European economies? A taxonomic analysis based on the INEC (index of national economies' circularity). Sustainability 2020, 12, 7613. [CrossRef]

50. Essex, B.; Koop, S.H.A.; Van Leeuwen, C.J. Proposal for a National Blueprint Framework to Monitor Progress on Water-Related Sustainable Development Goals in Europe. Environ. Manag. 2020, 65. [CrossRef]

51. Busu, M.; Trica, C.L. Sustainability of circular economy indicators and their impact on economic growth of the European Union. Sustainability 2019, 11, 5481. [CrossRef]

52. Avdiushchenko, A.; Zajaç, P. Circular economy indicators as a supporting tool for European regional development policies. Sustainability 2019, 11, 3025. [CrossRef]

53. Rokicki, T.; Perkowska, A.; Klepacki, B.; Bereziński, S.; Ziółkowska, P. The importance of higher education in the EU countries in achieving the objectives of the circular economy in the energy sector. Energies 2020, 13, 4407. [CrossRef]

54. Hysa, E.; Kruja, A.; Rehman, N.U.; Laurenti, R. Circular economy innovation and environmental sustainability impact on economic growth: An integrated model for sustainable development. Sustainability 2020, 12, 4831. [CrossRef]

55. Robaina, M.; Villar, J.; Pereira, E.T. The determinants for a circular economy in Europe. Environ. Sci. Pollut. Res. 2020, 27, 12566-12578. [CrossRef]

56. Melece, L. Challenges and opportunities of circular economy and green economy. In Proceedings of the 15th International Scientific Conference Engineering For Rural Development Proceedings, Jelgava, Latvia, 25-27 May 2016; Volume 15, pp. 1162-1169.

57. Rodriguez-Anton, J.M.; Rubio-Andrada, L.; Celemín-Pedroche, M.S.; Alonso-Almeida, M.D.M. Analysis of the relations between circular economy and sustainable development goals. Int. J. Sustain. Dev. World Ecol. 2019, 26, 708-720. [CrossRef]

58. Aceleanu, M.I.; Serban, A.C.; Suciu, M.-C.; Bitoiu, T.I. The management of municipal waste through circular economy in the context of smart cities development. IEEE Access 2019, 7, 133602-133614. [CrossRef]

59. Busu, C.; Busu, M. Modeling the circular economy processes at the EU level using an evaluation algorithm based on Shannon entropy. Processes 2018, 6, 225. [CrossRef]

60. Ghisellini, P.; Cialani, C.; Ulgiati, S. A review on circular economy: The expected transition to a balanced interplay of environmental and economic systems. J. Clean. Prod. 2016, 114, 11-32. [CrossRef]

61. Morseletto, P. Targets for a circular economy. Resour. Conserv. Recycl. 2020, 153, 104553. [CrossRef]

62. Murray, A.; Skene, K.; Haynes, K. The circular economy: An interdisciplinary exploration of the concept and application in a global context. J. Bus. Ethics 2017, 140, 369-380. [CrossRef] 
63. Kirchherr, J.; Reike, D.; Hekkert, M. Conceptualizing the Circular Economy: An analysis of 114 definitions. Resour. Conserv. Recycl. 2017, 127, 221-232. [CrossRef]

64. Niero, M.; Hauschild, M.Z.; Hoffmeyer, S.B.; Olsen, S.I. Combining eco-efficiency and eco-effectiveness for continuous loop beverage packaging systems: Lessons from the Carlsberg circular community. J. Ind. Ecol. 2017, 21, 742-753. [CrossRef]

65. Bocken, N.M.P.; de Pauw, I.; Bakker, C.; van der Grinten, B. Product design and business model strategies for a circular economy. J. Ind. Prod. Eng. 2016, 33, 308-320. [CrossRef]

66. Franklin-Johnson, E.L.; Figge, F.; Canning, L. Resource duration as a managerial indicator for Circular Economy performance. J. Clean. Prod. 2016, 133, 589-598. [CrossRef]

67. Hobson, K. Closing the loop or squaring the circle? Locating generative spaces for the circular economy. Prog. Hum. Geogr. 2016, 40, 88-104. [CrossRef]

68. Singh, J.; Ordonez, I. Resource recovery from post-consumer waste: Important lessons for the upcoming circular economy. J. Clean. Prod. 2016, 134, 342-353. [CrossRef]

69. Gregson, N.; Crang, M.; Fuller, S.; Holmes, H. Interrogating the circular economy: The moral economy of resource recovery in the EU. Econ. Soc. 2015, 44, 218-243. [CrossRef]

70. Haas, W.; Krausmann, F.; Wiedenhofer, D.; Heinz, M. How circular is the global economy?: An assessment of material flows, waste production, and recycling in the European Union and the world in 2005. J. Ind. Ecol. 2015, 19, 765-777. [CrossRef]

71. Ma, S.; Wen, Z.Z.; Chen, J.; Wen, Z.Z. Mode of circular economy in China's iron and steel industry: A case study in Wu'an city. J. Clean. Prod. 2014, 64, 505-512. [CrossRef]

72. Liu, J.Y. Circular economy and environmental efficiency-The case of traditional Hakka Living System. Procedia Soc. Behav. Sci. 2012, 57, 255-260. [CrossRef]

73. Geng, Y.; Zhu, Q.; Doberstein, B.; Fujita, T. Implementing China's Circular Economy Concept at the Regional Level: A Review of Progress in Dalian, China. Waste Manag. 2009, 29, 996-1002. [CrossRef]

74. Yuan, Z.; Bi, J.; Moriguichi, Y. The Circular Economy: A New Development Strategy in China. J. Ind. Ecol. 2008, 10, 4-8. [CrossRef]

75. Deloitte Sustainability Consulting Central Europe. Gospodarka o Obiegu Zamkniętym. Jak Wyzwolić Potencjał z Planowanych Zmian; Deloitte Sustainability Consulting Central Europe: Warszawa, Poland, 2016.

76. Lewandowski, M. Designing the Business Models for Circular Economy-Towards the Conceptual Framework. Sustainability 2016, 8, 43. [CrossRef]

77. Pieroni, M.P.P.; McAloone, T.C.; Pigosso, D.C.A. From theory to practice: Systematising and testing business model archetypes for circular economy. Resour. Conserv. Recycl. 2020, 162, 105029. [CrossRef]

78. Kristensen, H.S.; Mosgaard, M.A. A review of micro level indicators for a circular economy-Moving away from the three dimensions of sustainability? J. Clean. Prod. 2020, 243, 118531. [CrossRef]

79. Zhao, H.; Zhao, H.; Guo, S. Evaluating the comprehensive benefit of eco-industrial parks by employing multi criteria decision making approach for circular economy. J. Clean. Prod. 2017, 142, 2262-2276. [CrossRef]

80. Jia, F.; Yin, S.; Chen, L.; Chen, X. The circular economy in the textile and apparel industry: A systematic literature review. J. Clean. Prod. 2020, 259, 120728. [CrossRef]

81. Hossain, M.U.; Ng, S.T.; Antwi-Afari, P.; Amor, B. Circular economy and the construction industry: Existing trends, challenges and prospective framework for sustainable construction. Renew. Sustain. Energy Rev. 2020, 130, 109948. [CrossRef]

82. Boix, M.; Montastruc, L.; Pibouleau, L.; Azzaro-Pantel, C.; Domenech, S. Industrial water management by multiobjective optimization: From individual to collective solution through eco-industrial parks. J. Clean. Prod. 2012, 22, 85-97. [CrossRef]

83. Ghisellini, P.; Ripa, M.; Ulgiati, S. Exploring environmental and economic costs and benefits of a circular economy approach to the construction and demolition sector. A literature review. J. Clean. Prod. 2018, 178, 618-643. [CrossRef]

84. Eilering, J.; Vermeulen, W. Eco-industrial parks: Toward industrial symbiosis and utility sharing in practice. Prog. Ind. Ecol. 2004, 1, 245-270. [CrossRef]

85. Bechara, L.; Veiga, E.; Magrini, A. Eco-industrial park development in Rio de Janeiro, Brazil: A tool for sustainable development. J. Clean. Prod. 2009, 17, 653-661. [CrossRef]

86. Zeng, H.; Chen, X.; Xiao, X.; Zhou, Z. Institutional pressures, sustainable supply chain management, and circular economy capability: Empirical evidence from Chinese eco-industrial park firms. J. Clean. Prod. 2017, 155, 54-65. [CrossRef]

87. Johansson, N.; Henriksson, M. Circular economy running in circles? A discourse analysis of shifts in ideas of circularity in Swedish environmental policy. Sustain. Prod. Consum. 2020, 23, 148-156. [CrossRef]

88. Giannakitsidou, O.; Giannikos, I.; Chondrou, A. Ranking European countries on the basis of their environmental and circular economy performance: A DEA application in MSW. Waste Manag. 2020, 109, 181-191. [CrossRef]

89. Momete, D.C. A unified framework for assessing the readiness of European Union Economies to migrate to a circular modolling. Sci. Total Environ. 2020, 718, 137375. [CrossRef]

90. Club of Rome. A Study Pertaining to Finland, France, the Netherlands, Spain and Sweden. In The Circular Economy and Benefits for Society: Jobs and Climate Clear Winners in an Economy Based on Renewable Energy and Resource Efficiency; Club of Rome 2015. Available online: https://clubofrome.org/wp-content/uploads/2020/03/The-Circular-Economy-and-Benefits-for-Soci ety.pdf (accessed on 20 November 2020). 
91. Club of Rome. A Study Pertaining to the Norwegian Economy. In The Circular Economy and Benefits for Society: Jobs and Climate Clear Winners in an Economy Based on Renewable Energy and Resource Efficiency; A study Pertaining to the Norwegian Economy. Club of Rome. Available online: https://s3-eu-west-1.amazonaws.com/avfall-norge-no/dokumenter/The-Circular-E conomy-and-Benefits-for-Society.pdf (accessed on 20 November 2020).

92. Club of Rome. A study pertaining to the Czech Republic and Poland. In the Circular Economy and Benefits: Jobs and Climate Clear Winners in an Economy Based on Renewable Energy and Resource Efficiency; Club of Rome 2016. Available online: https:/ / circularecon omy.europa.eu/platform/sites/default/files/the-circular-economy-czech-republic-and-poland.pdf (accessed on 20 November 2020).

93. Hanumante, N.C.; Shastri, Y.; Hoadley, A. Assessment of circular economy for global sustainability using an integrated model. Resour. Conserv. Recycl. 2019, 151, 104460. [CrossRef]

94. Marino, C.; Cencioni, D. (Eds.) Circular Economy: Benefits and Good Practices; Edizioni Ambiente: Milano, Italy, 2018; ISBN 9-7888-6627-2304.

95. Xuan, L.; Baotong, D.; Hua, Y. The research based on the 3-R principle of Agro-Circular Economy Model-The Erhai Lake Basin as an example. Energy Procedia 2011, 5, 1399-1404. [CrossRef]

96. Schroeder, P.; Anggraeni, K.; Weber, U. The relevance of circular economy practices to the sustainable development goals. J. Ind. Ecol. 2019, 23, 77-95. [CrossRef]

97. Kravchenko, M.; McAloone, T.C.; Pigossoa, D.C.A. Implications of developing a tool for sustainability screening of circular economy initiatives. Procedia CIRP 2019, 80, 625-630. [CrossRef]

98. Schöggl, J.-P.; Stumpf, L.; Baumgartner, R.J. The narrative of sustainability and circular economy-A longitudinal review of two decades of research. Resour. Conserv. Recycl. 2020, 163, 105073. [CrossRef]

99. Chen, T.-L.; Kim, H.; Pan, S.-Y.; Tseng, P.-C.; Lin, Y.-P.; Chiang, P.-C. Implementation of green chemistry principles in circular economy system towards sustainable development goals: Challenges and perspectives. Sci. Total Environ. 2020, 716, 136998. [CrossRef]

100. The Council of the European Communities. Council Directive 75/442/EEC on Waste; The Council of the European Communities: Brussels, Belgium, 1975.

101. The Council of the European Communities. Council Regulation (EEC) No 259/93 on the Supervision and Control of Shipments of Waste Within, Into and Out of the European Community; The Council of the European Communities: Brussels, Belgium, 1993.

102. European Parliament; Council of the European Union. Directive 94/62/EC on Packaging and Packaging Waste; European Parliament and Council of the European Union: Brussels, Belgium, 1994.

103. The Council of the European Union. Council Directive 1999/31/EC on the Landfill of Waste; The Council of the European Union: Brussels, Belgium, 1999.

104. The Council of the European Communities. Council, Directive 85/337/EEC on the Assessment of the Effects of Certain Public and Private Projects on the Environment; The Council of the European Communities: Brussels, Belgium, 1985.

105. European Parliament; Council of the European Union. Directive 2000/53/EC on End-Of Life Vehicles; European Parliament and Council of the European Union: Brussels, Belgium, 2000.

106. European Parliament; Council of the European Union. Directive 2002/96/EC on Waste Electrical and Electronic Equipment (WEEE); European Parliament and Council of the European Union: Brussels, Belgium, 2003.

107. Commission of the European Communities. Communication from the Commission to the Council, the European Parliament, the European Economic and Social Committee and the Committee of the Regions. Thematic Strategy on the Sustainable Use of Natural Resources. $\operatorname{COM}(2005) 670$ Final; Commission of the European Communities: Brussels, Belgium, 2005.

108. European Commission. Roadmap to a Resource Efficient Europe COM(2011) 571 Final; European Commission: Brussels, Belgium, 2011.

109. European Commission. Communication from the Commission to the European Parliament, the Council, the European Economic and Social Committee and the Committee of the Regions, A New Circular Economy Action Plan For a Cleaner and More Competitive Europe, COM(2020) 98 Final; European Commission: Brussels, Belgium, 2020.

110. De Man, R.; Friege, H. Circular economy: European policy on shaky ground. Waste Manag. Res. 2016, 34, 93-95. [CrossRef]

111. Wilts, H.; von Gries, N.; Bahn-Walkowiak, B. From waste management to resource efficiency: The need for policy mixes. Sustainability 2016, 8, 622. [CrossRef]

112. Friant, M.C.; Vermeulen, W.J.V.; Salomone, R. Analysing European Union circular economy policies: Words versus actions. Sustain. Prod. Consum. 2021, 27, 337-353. [CrossRef]

113. Cayzer, S.; Griths, P.; Beghetto, V. Design of indicators for measuring product performance in the circular economy. Int. J. Sustain. Eng. 2017, 10, 289-298. [CrossRef]

114. Akerman, E. Development of Circular Economy Core Indicators for Natural Resources-Analysis of Existing Sustainability Indicators as a Baseline for Developing Circular Economy Indicators. Master's Thesis, Royal Institute of Technology, Stockholm, Sweden, 2016.

115. Vidal-Legaz, B.; Mancini, L.; Blengini, G.; Pavel, C.; Marmier, A.; Blagoeva, D.; Nita, V. EU Raw Materials Scoreboard; Publications Office of the European Union: Luxembourg, 2016.

116. European Commission. Communication from the Commission to the European Parliament, the Council, the European Economic and Social Committee and the Committee of the Regions on a Monitoring Framework for the Circular Economy (SWD (2018) 17, COM (2018) 29); European Commission: Brussels, Belgium, 2018. 
117. European Economic and Social Committee. EESC Opinion: Monitoring Framework for the Circular Economy; European Economic and Social Committee: Brussels, Belgium, 2018.

118. European Commission. Annual Sustainable Growth Strategy 2020, COM(2019) 650 Final, Communication from the Commission to the European Parliament, the Council, the European Central Bank, the European Economic And Social Committee, the Committee of the Regions and the European Investment Bank; European Commission: Brussels, Belgium, 2019.

119. Zeliaś, A. Taksonomiczna Analiza Przestrzennego Zróżnicowania Poziomu Zycia w Polsce w Ujęciu Dynamicznym; Wydawnictwo Akademii Ekonomicznej w Krakowie: Kraków, Poland, 2000.

120. Hellwig, Z. Zastosowanie metody taksonomicznej do typologicznego podziału krajów ze względu na poziom ich rozwoju oraz zasoby i strukturę wykwalifikowanych kadr. Przeglad Stat. 1968, 4, 307-326.

121. Sokołowski, A. Metody i Miary Porównania Poziomu i Dynamiki Rozwoju Regionów; Wydawnictwo Akademii Ekonomicznej w Krakowie: Kraków, Poland, 1998.

122. Schanes, K.; Jäger, J.; Drummond, P. Three Scenario Narratives for a Resource-Efficient and Low-Carbon Europe in 2050. Ecol. Econ. 2019, 155, 70-79. [CrossRef]

123. Domenech, T.; Bahn-Walkowiak, B. Transition Towards a Resource Efficient Circular Economy in Europe: Policy Lessons From the EU and the Member States. Ecol. Econ. 2019, 155, 7-19. [CrossRef]

124. European Environmental Agency (EEA). Resource Efficiency and the Circular Economy in Europe 2019-Even More from Less; European Environmental Agency Report No 26/2019; Publications Office of the European Union: Luxembourg, 2020.

125. Fitch-Roy, O.; Benson, D.; Monciardini, D. All around the world: Assessing optimality in comparative circular economy policy packages. J. Clean. Prod. 2021, 286, 125493. [CrossRef]

126. Squintani, L. Case Law of the Court of Justice of the European Union and the General Court. J. Eur. Environ. Plan. Law 2018, 15, 219-239. [CrossRef]

127. European Commission. Commission Proposes Fines and Refers Greece Back to the Court of Justice of the EU Over Persistent Poor Waste Water Treatment; European Commission: Brussels, Belgium, 2015.

128. Wilts, H.; O’Brien, M.A. Policy Mix for Resource Efficiency in the EU: Key Instruments, Challenges and Research Needs. Ecol. Econ. 2019, 155, 59-69. [CrossRef]

129. Hirschnitz-Garbers, M.; Hinzmann, M.; Watkins, E.; ten Brink, P.; Milios, L.; Soleille, S. A Framework for Member States to Support Business in Improving Its Resource Efficiency-An Analysis of Support Measures Applied in EU-28; Specific Contract No. 070201/2014/694448/ETU/ENV.F1; Institute for Environmental Studies/Ecologic Institute: Brussels, Belgium, 2015. 